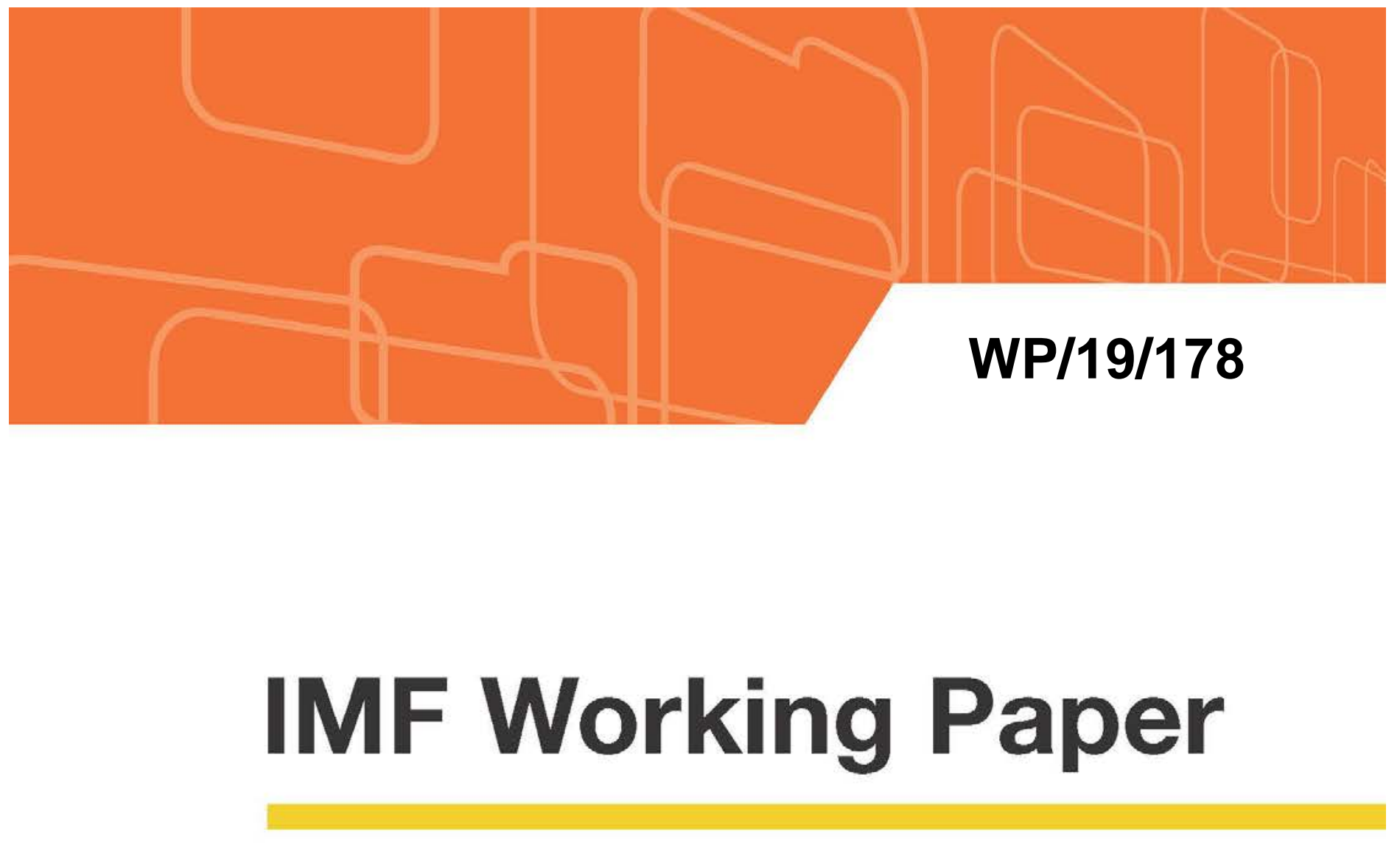

\title{
Weather Shocks and Output in Low-Income Countries: Adaptation and the Role of Policies
}

by Sebastian Acevedo Mejia, Claudio Baccianti, Mico Mrkaic, Natalija Novta, Evgenia Pugacheva, and Petia Topalova

IMF Working Papers describe research in progress by the author(s) and are published to elicit comments and to encourage debate. The views expressed in IMF Working Papers are those of the author(s) and do not necessarily represent the views of the IMF, its Executive Board, or IMF management.

$$
\text { I N T E R N A T I O N A L M O N E T A R Y F U N D }
$$




\title{
IMF Working Paper
}

Research Department

\section{Weather Shocks and Output in Low-Income Countries: The role of policies and adaptation ${ }^{1}$}

\author{
Prepared by Sebastian Acevedo Mejia, Claudio Baccianti, Mico Mrkaic, Natalija Novta, \\ Evgenia Pugacheva, and Petia Topalova ${ }^{2}$ \\ Authorized for distribution by Oya Celasun
}

August 2019

IMF Working Papers describe research in progress by the author(s) and are published to elicit comments and to encourage debate. The views expressed in IMF Working Papers are those of the author(s) and do not necessarily represent the views of the IMF, its Executive Board, or IMF management.

\begin{abstract}
We explore the extent to which macroeconomic policies, structural policies, and institutions can mitigate the negative relationship between temperature shocks and output in countries with warm climates. Empirical evidence and simulations of a dynamic general equilibrium model reveal that good policies can help countries cope with negative weather shocks to some extent. However, none of the adaptive policies we consider can fully eliminate the large aggregate output losses that countries with hot climates experience due to rising temperatures. Only curbing greenhouse gas emissions - which would mitigate further global warming — could limit the adverse macroeconomic consequences of weather shocks in a long-lasting way.
\end{abstract}

JEL Classification Numbers: Q58

Keywords: Climate change, Climate policy, Adaptation to climate change, Weather shock

\footnotetext{
${ }^{1}$ We thank Oya Celasun, Romain Duval, Stéphane Hallegatte, Warwick McKibbin, Edward Miguel, Gian Maria Milesi-Ferretti, Maurice Obstfeld, and Benjamin Olken, as well as participants at the IMF Brown Bag seminar for helpful comments and suggestions. We are grateful for contributions from Manoj Atolia, Ricardo Marto, and Marcos Poplawski-Ribeiro; and outstanding research assistance from Gavin Asdorian, Olivia Ma, Jilun Xing and Yuan Zeng. An earlier version of the analysis presented in this paper was published in Chapter 3 of the October 2017 World Economic Outlook.

22Authors’ E-Mail Addresses: SAcevedoMejia@imf.org, MMrkaic@imf.org, NNovta@imf.org, EPugacheva@imf.org, PTopalova@imf.org.
} 


\section{INTRODUCTION}

The average annual global temperature has increased by about $1^{\circ} \mathrm{C}$ in the past 40 years. In the absence of major cuts to greenhouse gas emissions, it could rise by $4^{\circ} \mathrm{C}$ or more by 2100 (IPCC, 2014). Rising temperatures reduce economic output in countries with hot climates, by lowering productivity, investment and labor supply (Burke, Hsiang and Miguel 2015; Acevedo Mejia et al. 2018). As temperatures continue to rise, there is an urgent need to adapt. This is particularly true for low-income countries, which are overwhelmingly situated in hot regions, contribute little to greenhouse gas emissions and bear the brunt of the negative economic costs of climate change. ${ }^{3}$

Despite the urgency of climate change adaptation in low income countries, policymakers and researchers have limited evidence about the effectiveness of policies in attenuating the negative effects of excessive heat. We aim to fill this gap. We present empirical evidence on the extent to which macroeconomic and structural policies, institutions and other country characteristics can mitigate the negative relationship between temperature and economic output at the country level. For example, we find that having policy buffers, such as low public debt to GDP, foreign aid and remittances help in the short run. Conversely, structural and institutional characteristics, typically associated with more long-term resilience, such as exchange rate flexibility, high financial sector liberalization, good infrastructure, democratic institutions and low inequality tend to help in the long run. We also shed light on the debate whether economic development shields countries from the negative effects of climate change (see Burke, Hsiang and Miguel, 2015 and Dell, Jones and Olken, 2012). Using subnational data, we find that hot regions in high-income countries on average sustain less economic damage than hot regions in low-income countries, which suggests that general economic development policies would complement any climate adaptation strategy. However, while policies can help, overall we find no evidence of fully successful adaptation at the macroeconomic level in the past 40 years.

We complement our empirical analysis with a dynamic general equilibrium model based on the Debt, Investment and Growth (DIG) model of Buffie et al. (2012). The model is used to simulate how specific macroeconomic policies and structural transformation help reduce the negative effect of temperature shocks. ${ }^{4}$ The model addresses a potential endogeneity concern

\footnotetext{
${ }^{3}$ As explained by McKibbin and Wilcoxen (2004), adaptation is the process of changing behavior in response to actual or expected climate changes, while mitigation is the act of reducing the cumulation of greenhouse gases in the atmosphere. Low income countries are not large emitters of greenhouse gases, and therefore have little direct impact on global mitigation efforts.

4 The DIG model captures various characteristics pertinent to low-income countries_-such as low public investment efficiency and high capital adjustment costs-and incorporates the structural transformation process. These aspects of the DIG model make it preferable for studying the impact of climate change in low-income countries relative to the Integrated Assessment Models (IAMs) more commonly used to assess climate change effects. Existing IAMs typically include various feedback loops among emissions, growth, and climate that are
} 
that only countries with the most severe climate shocks introduce climate adaptation policies, which then may erroneously appear to be relatively ineffective. Model simulations are consistent with our empirical findings about which specific policies might help and confirm that none can fully insulate countries from the negative effects of heat shocks.

Prior literature presents both positive and negative findings about the ability of different policies to help countries cope with weather shocks. In the case of natural disasters, good macroeconomic policies have been shown to help countries recover faster. For example, greater financial development, greater insurance penetration, higher quality institutions and democracy, flexible exchange rates, and overall development have all helped smooth the negative effects of natural disasters in the past. ${ }^{5}$ Climate-smart technologies likely further contributed toward generally successful global adaptation to cyclone risks (Hsiang and Narita 2012; Hsiang and Jina 2014). These findings fuel hopes that similar policies might be helpful in adaptation to negative weather shocks in general.

Yet, other researchers found virtually no adaptation to repeated negative weather shocks, especially if aggregate output or growth are considered. Specifically, the negative response of GDP to temperature shocks did not diminish over time (Burke, Hsiang, Miguel 2015; Dell, Jones, Olken 2012). Some of the particularly worrying findings on the lack of adaptation were in the agriculture sector (Schlenker and Roberts 2009; Burke and Emerick 2016), in studies of labor productivity (Heal and Park 2013), conflict (Burke et al. 2009) and crime (Ranson 2014). Despite the lack of adaptation in the past, some economists believe there is ample room for adaptation in the future. Costinot et al. (2016) argue that countries' comparative advantages will evolve with climate change, and as long as countries adjust their crop production accordingly and trade internationally, negative effects will be limited.

There is also the possibility that climate adaptation strategies could be successful at the individual level but_-if scaled up_-unsuccessful in the aggregate. For example, individuals have installed more air-conditioning in response to heat (Deschenes and Greenstone 2011; Barreca et al. 2016) and this has generally been viewed as a successful adaptation strategy. But in emerging markets-where electricity generation relies, to a large extent, on fossil fuels - the added electricity consumption due to greater use of air-conditioning will worsen pollution and future climate risks (Davis and Gertler 2015). In addition, exhaust from air-

\footnotetext{
less relevant for low-income countries who are not large emitters of greenhouse gases. IAMs are also not well suited to analyze sectoral issues and structural economic transformation that are of particular interest to policymakers.

${ }^{5}$ For the role of financial development see Burgess et al. (2014), Kahn (2005), McDermott, Barry, and Tol (2013), Felbermayr and Gröschl (2014), and Noy (2009). For the role of insurance penetration, see Von Peter, Dahlen, and Saxena (2012), Breckner et al. (2016), and Lee et al. (2016). For the role of institutional strength and democracy, see Kahn (2005), Noy (2009), Felbermayr and Groeschl (2014), and Cavallo et al. (2013). For the role of exchange rates in reducing damage from extreme weather events and natural disasters see Ramcharan (2009). For the role of development status, see Raddatz (2009), Noy (2009), and Von Peter, Dahlen, and Saxena (2012).
} 
conditioning machines and facilities can give rise to local pockets of hot air, which can present significant negative externalities for nearby populations, particularly in densely populated urban areas.

These conflicting findings about the success of various adaptation policies call for a comprehensive cross-country analysis of a wide range of potentially useful policies. We provide such analysis through a unified empirical investigation, and model simulations of the effectiveness of each of the policies that we can measure in a global setting in mitigating the negative effects of climate change. Our analysis is a necessary first step to help policymakers mainstream climate adaptation policies in their agendas (Hug et al. 2004). To the best of our knowledge, we offer the first such comprehensive and unified study of the effectiveness of climate adaptation policies globally.

Unfortunately, our findings suggest that, even though policies have a role to play, they are not enough to eliminate the negative effect of temperature increases. Ultimately, only limiting greenhouse gas emissions - which the scientific community agrees would limit further global warming - would deliver permanent relief from future negative climate shocks.

This paper is organized as follows: Section II describes the different types of policies that we study; Section III introduces the data and outlines our empirical approach and findings; Section IV discusses our model approach and findings; and Section V concludes. Annexes provide further details regarding our empirical analyses and model simulations.

\section{Climate Adaptation Policy: A Toolkit}

To structure our analytical approach, we begin by discussing the toolkit of policies available to policymakers and private agents to cope with weather shocks, as summarized in Figure 1. The toolkit includes domestic policy actions and private choices that may help insulate economic activity from weather shocks and the risks that accompany climate change. These policies and actions range from the standard set of macroeconomic and structural policies that have been shown to enhance the resilience of economic growth (e.g. fiscal buffers, social safety nets), to specific strategies designed to adapt to climate change in individual countries (e.g. climate-smart infrastructure investments), to sovereign insurance (e.g. catastrophe bonds). Even private agents' decisions to migrate to countries that are less affected by climate change can serve as an extreme form of adaptation.

Fluctuations in weather can be viewed as one of many shocks that affect macroeconomic performance. As such, their consequences could be attenuated by general macroeconomic and structural policies that enhance countries' ex ante and ex post resilience to shocks, as depicted in the first two columns in Figure 1. While priorities vary depending on each country's specific circumstances, policies may include those that seek to limit the short-term impact when shocks occur, help the economy recover faster, and reduce vulnerability to 
future shocks. Policies reinforce each other to achieve these goals. For example, countries with buffers (fiscal and monetary space, large international reserves, access to foreign aid) and well-targeted social safety nets may be better placed to deliver support to people affected by weather shocks, thus smoothing consumption in the short term.

Figure 1. Coping with Weather Shocks and Climate Change: A Toolkit

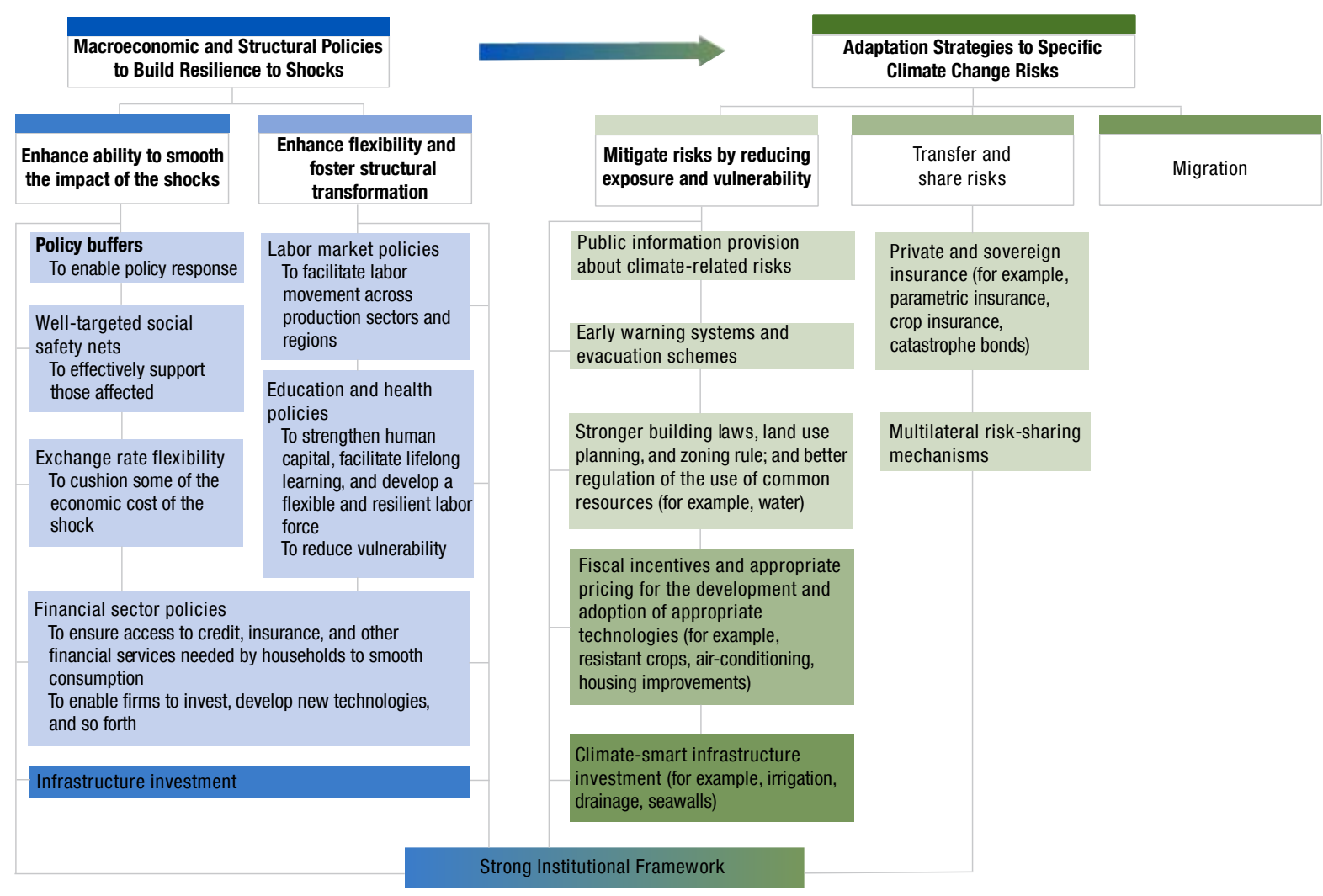

Source: IMF staff compilation.

Adjusting to climate change in the long run will likely require reallocating people and capital across sectors and regions as production and trade patterns shift. Policies and institutions that facilitate the needed reallocation, such as those that ensure access to finance, labor-market flexibility, and investment in human capital and infrastructure, could speed up recovery and foster the structural transformation necessary to reduce vulnerability. ${ }^{6}$ In the long run, investments in education and health are also considered important for helping people build resilience to weather shocks. Healthier people generally have lower mortality and morbidity in response to heat waves, and better education can help them prepare and better respond to weather shocks. In fact, an overall higher level of development is associated with lower

\footnotetext{
${ }^{6}$ The classification of policies presented in Figure 1 is rather loose. Greater financial access could help farmers both smooth consumption when higher temperatures damage crops and invest in the technology needed to prevent future damage (such as buying heat-resistant seeds).
} 
vulnerability to shocks (e.g. because people live in higher quality housing), and potentially because more developed countries also tend to have good macroeconomic, structural and climate adaptation strategies.

Mitigating the risks associated with climate change requires some specific adaptation policies, as depicted in the last three columns in Figure 1. Once the key climate change risks are identified for a particular location, both "soft" and "hard" adaptation measures can be applied (Hallegatte 2009). Soft measures may include strengthening public information provision, building codes, land use and zoning laws, and devising warning and evacuation systems, along with targeted incentives for climate-related technologies (such as centralized cooling systems) and transferring and sharing risks related to weather events (such as natural disasters, which may increase in frequency) through financial markets. Hard measures may include investment in climate-smart infrastructure such as retrofitting properties, building (or upgrading) irrigation or drainage systems, building seawalls, and the like. ${ }^{7}$ Appropriate adaptation measures are highly specific to the climate-related risks in each location and national circumstances; the infrastructure requirements for a flood-prone area would be vastly different from those of an area that is frequently exposed to droughts. This specificity, together with lack of comparable data on adaptation measures, precludes cross-country empirical analysis.

\section{EMPIRICAL ANALYSIS}

Our key data sources include the IMF World Economic Outlook (WEO), World Bank World Development Indicators (WDI), and University of East Anglia's Climate Research Unit (CRU) historical temperature and precipitation databases. Annex Table 1 provides the specifics on the data sources and exact definitions of all policy and adaptation variables used in the analysis. Per capita GDP are taken from the WEO and WDI, while historical temperature and precipitation are from CRU. We construct average annual temperature and precipitation by aggregating weather data at the grid-cell level, provided by CRU at $0.5 \times 0.5$ degree resolution, to the level of the country using the 1950 population in each cell as weights. This method allows us to account for differences in population density within countries and captures the average weather experienced by a person in the country.

In section A, we review the baseline specification, used to estimate the effect of weather shocks on growth of real GDP per capita, and introduce our overall empirical strategy. In section B, we explore whether macroeconomic policies and climate change adaptation strategies can mute the negative effect of temperature increases on growth of real GDP per capita. In section C, we use subnational data to see how the level of development may affect

\footnotetext{
${ }^{7}$ See Cabezon et al. (2015); Farid et al. (2016); Hallegatte (2009); Hallegatte, Lecocq, and de Perthuis (2011); Hallegatte et al. (2016); IMF (2016a,b); IPCC (2014); and OECD (2015) for a comprehensive discussion of various climate change adaptation strategies.
} 
the relationship between temperature and growth of GDP. In section D, we examine whether there is evidence of successful adaptation by countries over time.

\section{A. Baseline specification}

Our baseline specification, explained also in Acevedo Mejia et al. (2018), uses Jordà’s (2005) local projection method to trace out the impulse response function of real per capita GDP to a weather shock. Similar to Dell, Jones, and Olken (2012) and Burke, Hsiang, and Miguel (2015), we use within-country and across-country year-to-year fluctuations in temperature and precipitation to identify their causal effect on aggregate outcomes, both contemporaneously and over the medium term.

We derive the impulse response by estimating a set of regressions:

$$
\begin{aligned}
y_{i, t+h}-y_{i, t-1}=\beta_{1}^{h} c_{i, t}+\beta_{2}^{h} c_{i, t}^{2}+\gamma_{1}^{h} c_{i, t-1} & +\gamma_{2}^{h} c_{i, t-1}^{2}+\sum_{j=1}^{h-1} \delta_{1}^{h} c_{i, t+h-j}+\sum_{j=1}^{h-1} \delta_{2}^{h} c_{i, t+h-j}^{2} \\
& +\varphi_{1}^{h} \Delta y_{i, t-1}+\mu_{i}^{h}+\theta_{r, t}^{h}+\varepsilon_{i, t}^{h},
\end{aligned}
$$

in which $i$ indexes countries, $t$ indexes years, and $h$ indexes the estimation horizon (from horizon 0 , which captures the contemporaneous effect, up to horizon 7 , which captures the effect 7 years after the shock). Regressions for each horizon are estimated separately. The dependent variable is the cumulative growth of real GDP per capita between horizons $t-1$ and $t+h$, measured as difference in the natural logarithms $\left(y_{i, t}\right)$. The regressions control for one lag of the dependent and weather variables and for forwards of the weather variables, as suggested by Teulings and Zubanov (2014). Country fixed effects $\left(\mu_{i}^{h}\right)$ control for all timeinvariant country differences, such as latitude and average growth rates, while time fixed effects interacted with region dummies $\left(\theta_{r, t}^{h}\right)$ control for the common effect of all annual shocks across countries within a region. ${ }^{8}$ Standard errors are clustered at the country level.

Following Burke, Hsiang, and Miguel (2015), our baseline specification is quadratic in the weather variables, $c_{i, t}$, which comprise average annual temperature and precipitation. This allows us to capture non-linearities in the response of output to a temperature shock: for countries with colder climates an increase in temperature might be beneficial, whereas for countries that are already hot a further increase in temperature could be very detrimental. The effect of a $1^{\circ} \mathrm{C}$ increase in temperature on the level of output per capita at horizon $h$ can be derived by differentiating equation (1) with respect to temperature:

$$
\frac{\partial\left(y_{i, t+h}-y_{i, t-1}\right)}{\partial T_{i, t}}=\beta_{1}^{h}+2 \beta_{2}^{h} T_{i, t},
$$

and evaluating it for a given temperature $T_{i, t}$.

\footnotetext{
${ }^{8}$ We use indicators for six regions as defined by the World Bank: East Asia and Pacific, Europe and Central Asia, Latin American and the Caribbean, Middle East and North Africa, North America, South Asia, and Sub-Saharan Africa.
} 
Table 1. Effect of Temperature Shocks on Output

\begin{tabular}{|c|c|c|}
\hline A. Real Output per Capita Growth & (1) & (2) \\
\hline Temperature & $\begin{array}{l}1.347^{\star \star \star} \\
(0.357)\end{array}$ & $\begin{array}{l}-1.154^{\star \star \star} \\
(0.320)\end{array}$ \\
\hline Temperature $^{2}$ & $\begin{array}{l}-0.051^{\text {***}} \\
(0.011)\end{array}$ & \\
\hline Precipitation & $\begin{array}{r}0.110 \\
(0.104)\end{array}$ & $\begin{array}{r}0.005 \\
(0.034)\end{array}$ \\
\hline Precipitation $^{2}$ & $\begin{array}{l}-0.003 \\
(0.002)\end{array}$ & \\
\hline Threshold Temperature $\left({ }^{\circ} \mathrm{C}\right)$ & $13^{\circ}$ & \\
\hline Adjusted $R^{2}$ & 0.14 & 0.09 \\
\hline Number of Countries & 189 & 127 \\
\hline Number of Observations & 8,815 & 6,135 \\
\hline \multicolumn{3}{|c|}{ B. Impact of a $1^{\circ} \mathrm{C}$ Increase in Temperature on Real Output per Capita } \\
\hline $\mathrm{AE}\left(\mathrm{T}=11^{\circ} \mathrm{C}\right)$ & $\begin{array}{r}0.218 \\
(0.196)\end{array}$ & \\
\hline $\mathrm{EM}\left(\mathrm{T}=22^{\circ} \mathrm{C}\right)$ & $\begin{array}{l}-0.911^{* * *} \\
(0.264)\end{array}$ & \\
\hline $\operatorname{LIDC}\left(\mathrm{T}=25^{\circ} \mathrm{C}\right)$ & -1.219 *** & \\
\hline
\end{tabular}

Source: authors' calculations.

Note: The table presents results from estimating equation (1), with separate regressions for each horizon. Panel $A$ reports the estimated coefficients on the weather variables for horizon 0 (contemporaneous). The specification in column (1) is estimated for the full sample of countries with quadratic terms for temperature and precipitation to capture the non-linear impact of weather shocks. For this quadratic specification, panel B shows the marginal impact of a change in temperature computed as per equation (2) at the median temperature (T) of advanced economies (AE), emerging markets (EM), and lowincome developing countries (LIDC) contemporaneously. Column (2) reports the coefficients on temperature and precipitation from a linear specification estimated on a sample of countries with average temperature above $15^{\circ} \mathrm{C}$. All specifications control for country and region-year fixed effects. Standard errors reported in parenthesis are clustered at the country level

${ }^{*} \mathrm{p}<0.1 ;{ }^{* *} \mathrm{p}<0.05 ;{ }^{* \star *} \mathrm{p}<0.01$.

The results from estimating equation (1) at horizon $\mathrm{h}=0$ are presented in Table 1 , Panel A, column $1 .{ }^{9}$ The results confirm the nonlinear relationship between temperature and per capita GDP, uncovered by Burke, Hsiang
Figure 2. Effect of Temperature Increase on Real per Capita Output over Time

(Percent; years on $x$-axis)
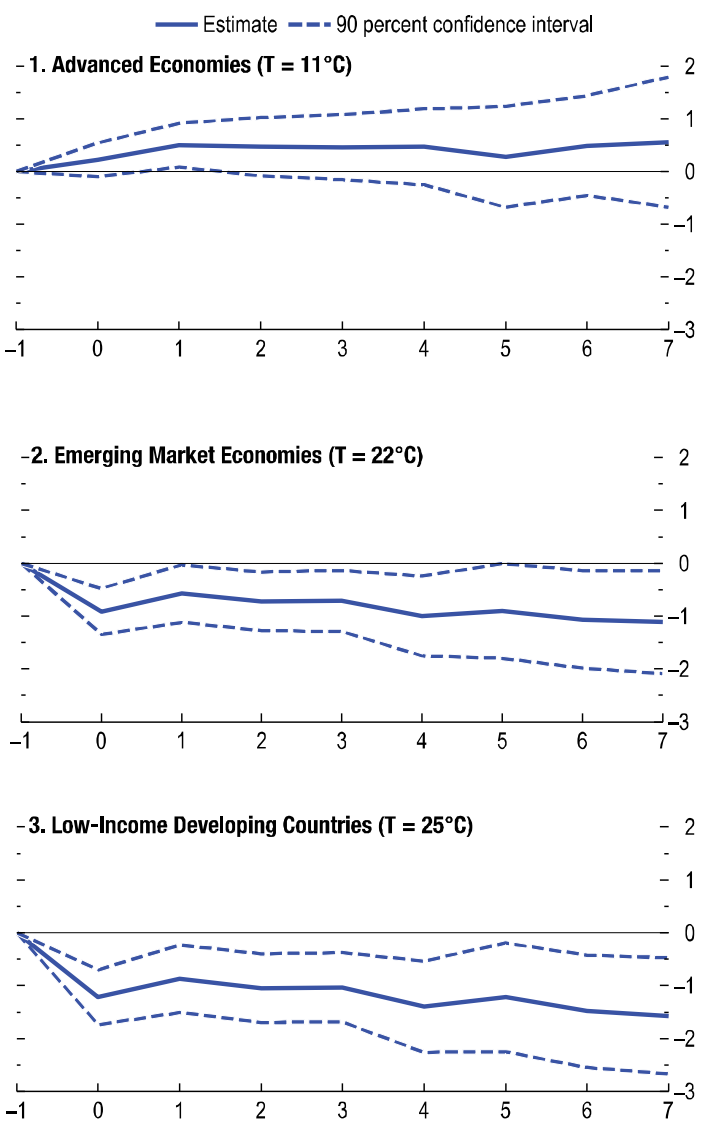

Source: IMF staff calculations.

Note: The panels depict the impulse response of per capita output to a $1^{\circ} \mathrm{C}$ increase in temperature estimated at the median temperature of advanced economies, emerging markets and low-income developing countries. Horizon 0 is the year of the shock. $\mathrm{T}=$ temperature. and Miguel (2015), and suggest highly uneven effects of warming across the globe. In countries with cooler climates, an increase in temperature boosts economic output, while in countries with higher average temperature, a rise in temperature suppresses economic growth. As low-income countries happen to have much warmer climates, the results imply that an increase in temperature would have much more deleterious effects than in advanced economies (Table 1, Panel B). Notably, for low-income countries even seven years after the shock the effect remains negative and significant. This is depicted in Figure 2, which plots the effect on cumulative per capita output from a $1^{\circ} \mathrm{C}$ increase in temperature estimated at the temperature of the median advanced (panel 1), emerging market (panel 2) and low-income (panel 3) country at horizons 0 through 7.

The quadratic specification further allows us to estimate the threshold temperature where the effect switches from positive to negative in order to zoom-in on countries with expected

\footnotetext{
${ }^{9}$ For baseline estimates of medium-term effects of temperature and precipitation on growth of GPD per capita, as well as their channels of impact, please see Acevedo Mejia et al. (2018).
} 
negative impact of a temperature increase, such as most low-income developing countries. The threshold temperature can be derived by setting equation (2) to zero, resulting in $\mathrm{T}_{i, t}^{t h r e s h o l d}=-\beta_{1}^{h} / 2 \beta_{2}^{h}$. Following the specification in column 1 of Table 1 and based on a number of alternative specifications as robustness checks discussed in Acevedo Mejia et al. (2018), we find the threshold temperature to range between $13^{\circ} \mathrm{C}-15^{\circ} \mathrm{C}$.

\section{B. The Role of Domestic Policies and Institutions: Empirical Evidence}

To study the extent to which macroeconomic and structural policies and country characteristics mute the effect of weather shocks, we modify the analysis described above in two ways. First, we allow the response of per capita output to weather shocks to vary with various proxies for policy and institutional settings. Specifically, we modify equation (1) to include an interaction term between the weather shock and the policy variable:

$$
\begin{gathered}
y_{i, t+h}-y_{i, t-1}=\beta_{1}^{h} c_{i, t}+\gamma_{1}^{h}\left(c_{i, t} \times p_{i, t-1}\right)+\delta_{1}^{h} p_{i, t-1}+\beta_{2}^{h} c_{i, t-1}+\gamma_{2}^{h}\left(c_{i, t-1} \times p_{i, t-2}\right)+\delta_{2}^{h} p_{i, t-2} \\
+\sum_{j=1}^{h-1} \beta_{3}^{h j} c_{i, t+h-j}+\varphi_{1}^{h} \Delta y_{i, t-1}+\mu_{i}^{h}+\theta_{r, t}^{h}+\varepsilon_{i, t}^{h} .
\end{gathered}
$$

Second, we restrict the sample to countries with average annual temperature exceeding $15^{\circ} \mathrm{C}$, in which an increase in temperature has a statistically significant linear negative impact on economic activity (as shown in column 2 of Table 1). Consequently, the weather shock $c_{i, t}$ refers to average annual temperature and precipitation. Most of the policy variables $p_{i, t}$ are lagged to minimize reverse causality concerns and are included one at a time.

Guided by the toolkit presented in Figure 1, we consider two sets of policies and country characteristics: (i) the availability of policy buffers that can help countries smooth shocks in the short run and limit their negative impacts; and (ii) structural characteristics that may make it easier for countries to adapt to climate change in the long run, such as the availability of financial and human capital, strong institutions and the like. For ease of interpretation, each policy variable is transformed into an indicator variable depending on whether, in year $t$, the country is above or below the median value of this particular policy in the estimation sample. An exception to this approach is the measurement of buffers. A country is considered to have (1) fiscal buffers if public debt as a share of GDP is less than the 75th percentile, (2) monetary buffers if annual inflation is less than 10 percent, (3) high international reserves if international reserves minus gold can cover at least four months of imports, (4) high foreign aid if foreign aid inflows as a share of GDP are in the 75th percentile, and (5) high remittances if per capita remittances in real US dollars received are greater than the 75th percentile. For exchange rate policy, the analysis uses an indicator if the de facto exchange rate regime of a country is not pegged based on the coarse classification of Reinhart and Rogoff (2004).

It is important to emphasize that it is difficult to interpret causally the coefficients on the interaction terms, since the variation in policies and institutions across countries and over 
time is not random. Policies and institutions could also be correlated with time-varying relevant country attributes that are not controlled for in the regression. Moreover, policy data availability varies significantly in both temporal and country coverage, resulting in differences in the estimation sample.

Figure 3. The Role of Policy Buffers (Percent; years on $\mathrm{x}$-axis)
Figure 4. The Role of Structural Policies and Institutions (Percent; years on $\mathrm{x}$-axis)
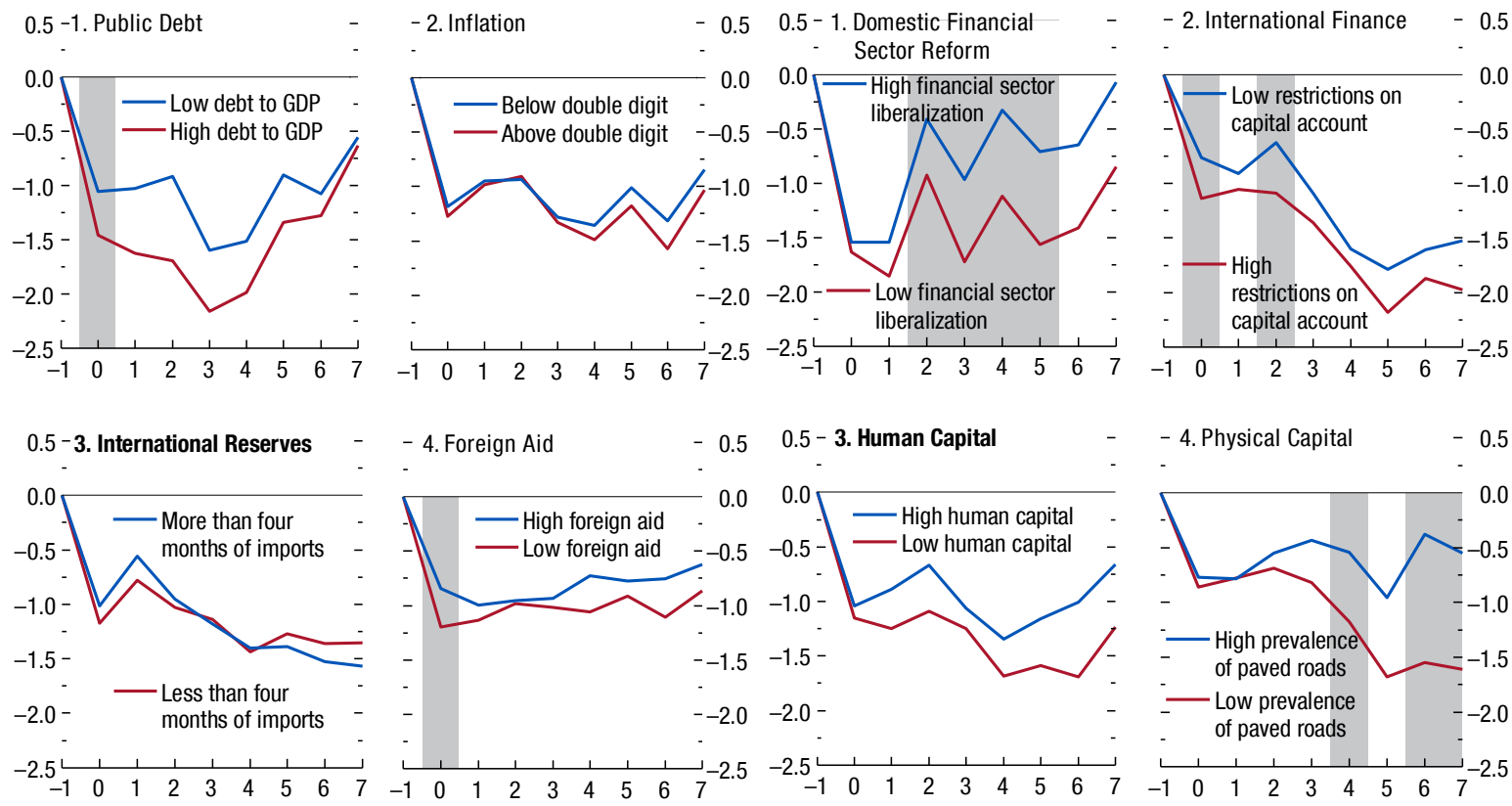

0.5 - 5. Remittances

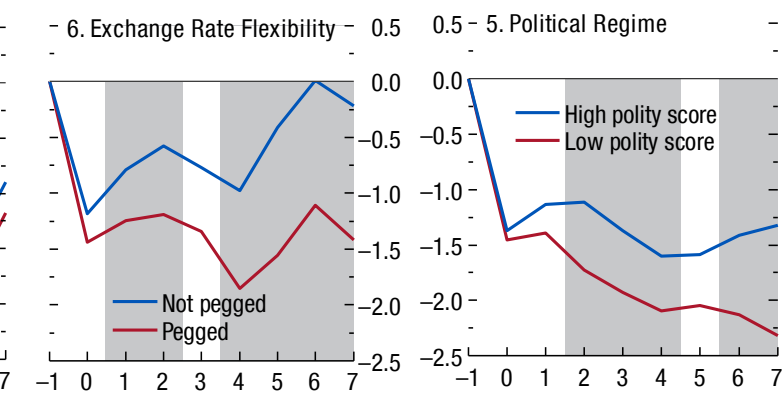

0.5 - 5. Political Regime
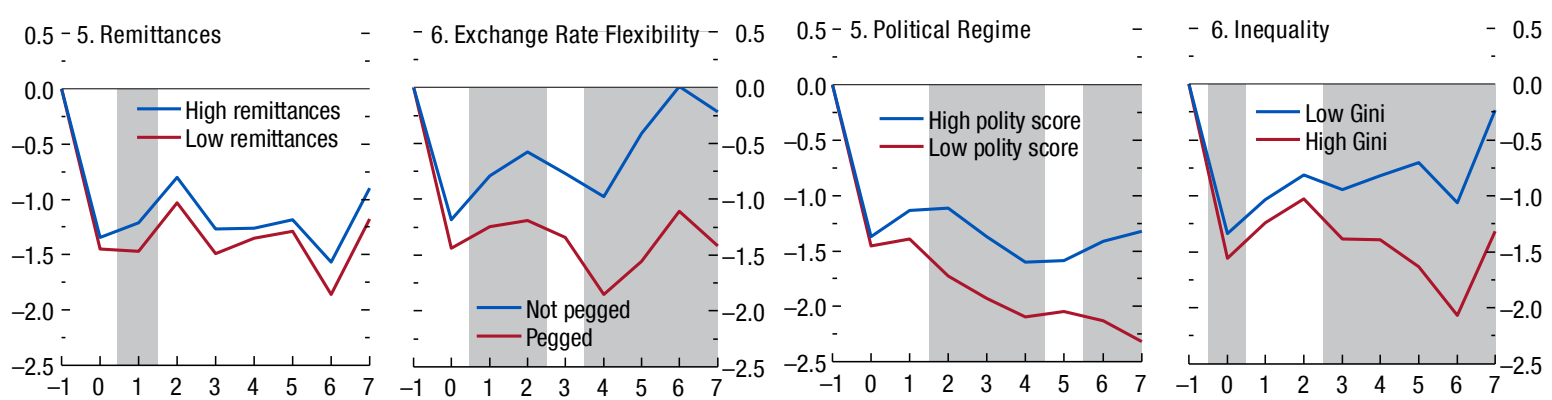

Source: IMF staff calculations.

Source: IMF staff calculations.

Note: The panels depict how the effect of $a 1^{\circ} \mathrm{C}$ increase in temperature on per Note: The panels depict how the effect of a $1^{\circ} \mathrm{C}$ increase in temperature on per capita output in the sample of countries with average temperature exceeding $15^{\circ} \mathrm{C}$ capita output in the sample of countries with average temperature exceeding $15^{\circ} \mathrm{C}$ varies with the empirical proxy of a policy buffer. Horizon 0 is the year of the shock. varies with the empirical proxies of structural policies and institutional settings Gray areas indicate that the blue and red lines are significantly different from each Horizon 0 is the year of the shock. Gray areas indicate that the blue and red lines other at the 15 percent level. are significantly different from each other at the 15 percent level.

Figures 3 and 4, and Tables 2 and 3 present the main findings. For each policy, the tables report the estimated effect of a $1^{\circ} \mathrm{C}$ increase in temperature on per capita output at horizons 0 through 7, where the policy is not in place and where the policy is in place. The tables also report the $p$-value of a statistical test of the difference between the effect of temperature in different policy scenarios. 
Table 2. Role of Policy Buffers

\begin{tabular}{|c|c|c|c|c|c|c|c|c|c|}
\hline \multirow{3}{*}{$\begin{array}{l}\text { Impact of a } 1^{\circ} \mathrm{C} \text { Increase in } \\
\text { Temperature on per } \mathrm{C} \text { apita } 0 \text { utput }\end{array}$} & (1) & $(2)$ & (3) & (4) & $(5)$ & $(6)$ & $(7)$ & (8) & (9) \\
\hline & \multicolumn{3}{|c|}{ Public Debt } & \multicolumn{3}{|c|}{ Inflation } & \multicolumn{3}{|c|}{ International Reserves } \\
\hline & Low & $\mathrm{High}$ & P-value & Low & $\mathrm{High}$ & P-value & $\mathrm{High}$ & Low & P-value \\
\hline Horizon 0 & $\begin{array}{l}-1.057^{\star * \star} \\
(0.387)\end{array}$ & $\begin{array}{l}-1.460^{* * *} \\
(0.352)\end{array}$ & 0.09 & $\begin{array}{l}-1.183^{* * *} \\
(0.295)\end{array}$ & $\begin{array}{l}-1.275^{\star * \star} \\
(0.322)\end{array}$ & 0.40 & $\begin{array}{l}-1.015^{* *} \\
(0.414)\end{array}$ & $\begin{array}{l}-1.171^{* \star *} \\
(0.314)\end{array}$ & 0.52 \\
\hline Horizon 1 & $\begin{array}{l}-1.029 \text { ** } \\
(0.471)\end{array}$ & $\begin{array}{l}-1.627^{\star * *} \\
(0.466)\end{array}$ & 0.24 & $\begin{array}{l}-0.9522^{* * *} \\
(0.362)\end{array}$ & $\begin{array}{l}-0.985 \text { ** } \\
(0.425)\end{array}$ & 0.87 & $\begin{array}{l}-0.556 \\
(0.492)\end{array}$ & $\begin{array}{l}-0.782 \text { ** } \\
(0.395)\end{array}$ & 0.36 \\
\hline Horizon 2 & $\begin{array}{l}-0.914 \text { * } \\
(0.492)\end{array}$ & $\begin{array}{l}-1.695^{\text {** }} \\
(0.690)\end{array}$ & 0.24 & $\begin{array}{l}-0.933 \\
(0.375)\end{array}$ & $\begin{array}{l}-0.907 \\
(0.416)\end{array}$ & 0.87 & $\begin{array}{l}-0.952 \text { ** } \\
(0.390)\end{array}$ & $\begin{array}{l}-1.030^{* * \star} \\
(0.382)\end{array}$ & 0.58 \\
\hline Horizon 3 & $\begin{array}{l}-1.597^{\star \star \star} \\
(0.525)\end{array}$ & $\begin{array}{l}-2.1599^{\star \star *} \\
(0.758)\end{array}$ & 0.34 & $\begin{array}{l}-1.279^{\star * \star} \\
(0.419)\end{array}$ & $\begin{array}{l}-1.333^{\star \star \star} \\
(0.429)\end{array}$ & 0.79 & $\begin{array}{l}-1.182^{\star \star \star} \\
(0.404)\end{array}$ & $\begin{array}{l}-1.140^{\star \star \star} \\
(0.411)\end{array}$ & 0.78 \\
\hline Horizon 4 & $\begin{array}{l}-1.512 \\
(0.704)\end{array}$ & $\begin{array}{l}-1.986 \text { ** } \\
(0.972)\end{array}$ & 0.46 & $\begin{array}{l}-1.355^{\text {** }} \\
(0.560)\end{array}$ & $\begin{array}{l}-1.487 \\
(0.571)\end{array}$ & 0.55 & 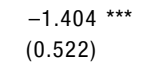 & $\begin{array}{l}-1.440 \text { ***} \\
(0.522)\end{array}$ & 0.85 \\
\hline Horizon 5 & $\begin{array}{l}-0.899 \\
(0.758)\end{array}$ & $\begin{array}{l}-1.341 \\
(0.936)\end{array}$ & 0.42 & $\begin{array}{l}-1.014 \text { * } \\
(0.583)\end{array}$ & $\begin{array}{l}-1.181 \text { * } \\
(0.628)\end{array}$ & 0.46 & $\begin{array}{l}-1.390 \text { ** } \\
(0.609)\end{array}$ & $\begin{array}{l}-1.270 \text { ** } \\
(0.603)\end{array}$ & 0.66 \\
\hline Horizon 6 & $\begin{array}{l}-1.075 \\
(0.844)\end{array}$ & $\begin{array}{l}-1.277 \\
(0.867)\end{array}$ & 0.68 & $\begin{array}{l}-1.315^{\text {** }} \\
(0.626)\end{array}$ & $\begin{array}{l}-1.572 \text { ** } \\
(0.675)\end{array}$ & 0.32 & $\begin{array}{l}-1.524 \\
(0.614)\end{array}$ & $\begin{array}{l}-1.362 \\
(0.597)\end{array}$ & 0.55 \\
\hline Horizon 7 & $\begin{array}{l}-0.552 \\
(0.819)\end{array}$ & $\begin{array}{l}-0.633 \\
(0.859)\end{array}$ & 0.87 & $\begin{array}{l}-0.842 \\
(0.610)\end{array}$ & $\begin{array}{l}-1.032 \\
(0.628)\end{array}$ & 0.52 & $\begin{array}{l}-1.566 \text { ** } \\
(0.629)\end{array}$ & $\begin{array}{l}-1.353^{\text {** }} \\
(0.611)\end{array}$ & 0.49 \\
\hline Adjusted $R^{2}$ & \multicolumn{3}{|c|}{0.15} & \multicolumn{3}{|c|}{0.12} & \multicolumn{3}{|c|}{0.09} \\
\hline Number of Countries & \multicolumn{3}{|c|}{119} & \multicolumn{3}{|c|}{122} & \multicolumn{3}{|c|}{127} \\
\hline Number of 0 bservations & \multicolumn{3}{|c|}{4,492} & \multicolumn{3}{|c|}{5,365} & \multicolumn{3}{|c|}{6,135} \\
\hline Impact of a $1^{\circ} \mathrm{C}$ Increase in & \multicolumn{3}{|c|}{ Foreign Aid } & \multicolumn{3}{|c|}{ Remittances } & \multicolumn{3}{|c|}{ Exchange Rate Flexibility } \\
\hline Temperature on per Capita 0 utput & High & Low & $P$-value & $\mathrm{High}$ & Low & $P$-value & Not Pegged & Pegged & P-value \\
\hline Horizon 0 & $\begin{array}{l}-0.840 \text { ** } \\
(0.380)\end{array}$ & $\begin{array}{l}-1.194^{\star \star \star} \\
(0.334)\end{array}$ & 0.06 & $\begin{array}{l}-1.345^{\star \star \star} \\
(0.337)\end{array}$ & 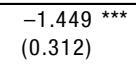 & 0.34 & $\begin{array}{l}-1.183^{\text {}} \\
(0.321)\end{array}$ & $\begin{array}{l}-1.436 \\
(0.315)\end{array}$ & 0.16 \\
\hline Horizon 1 & $\begin{array}{l}-0.996 \\
(0.448)\end{array}$ & $\begin{array}{l}-1.1322^{* * *} \\
(0.396)\end{array}$ & 0.59 & $\begin{array}{l}-1.212^{* * *} \\
(0.389)\end{array}$ & $\begin{array}{l}-1.4722^{* * *} \\
(0.410)\end{array}$ & 0.13 & $\begin{array}{l}-0.792 \text { * } \\
(0.426)\end{array}$ & $\begin{array}{l}-1.2499^{* * *} \\
(0.415)\end{array}$ & 0.08 \\
\hline Horizon 2 & $\begin{array}{l}-0.958^{\star *} \\
(0.433)\end{array}$ & $\begin{array}{l}-0.979 * * \\
(0.401)\end{array}$ & 0.94 & $\begin{array}{l}-0.799 * \\
(0.436)\end{array}$ & $\begin{array}{l}-1.030^{\star \star} \\
(0.456)\end{array}$ & 0.31 & $\begin{array}{l}-0.575 \\
(0.483)\end{array}$ & $\begin{array}{l}-1.191^{\star *} \\
(0.503)\end{array}$ & 0.08 \\
\hline Horizon 3 & $\begin{array}{l}-0.931 * \\
(0.551)\end{array}$ & $\begin{array}{l}-1.020^{* *} \\
(0.475)\end{array}$ & 0.74 & $\begin{array}{l}-1.271^{\star *} \\
(0.530)\end{array}$ & $\begin{array}{l}-1.488^{\star \star *} \\
(0.499)\end{array}$ & 0.45 & $\begin{array}{l}-0.769 \\
(0.574)\end{array}$ & $\begin{array}{l}-1.3422^{\text {** }} \\
(0.600)\end{array}$ & 0.20 \\
\hline Horizon 4 & $\begin{array}{l}-0.724 \\
(0.672)\end{array}$ & $\begin{array}{l}-1.061 \\
(0.539)\end{array}$ & 0.32 & $\begin{array}{l}-1.260 \text { * } \\
(0.678)\end{array}$ & $\begin{array}{l}-1.348 \text { ** } \\
(0.664)\end{array}$ & 0.77 & $\begin{array}{r}-0.975 \\
(0.781)\end{array}$ & $\begin{array}{l}-1.853 \\
(0.801)\end{array}$ & 0.08 \\
\hline Horizon 5 & $\begin{array}{r}-0.772 \\
(0.635)\end{array}$ & $\begin{array}{l}-0.913 \text { * } \\
(0.534)\end{array}$ & 0.70 & $\begin{array}{l}-1.182 \text { * } \\
(0.691)\end{array}$ & $\begin{array}{l}-1.287^{\star \star} \\
(0.644)\end{array}$ & 0.76 & $\begin{array}{r}-0.408 \\
(0.830)\end{array}$ & $\begin{array}{l}-1.556 \text { * } \\
(0.851)\end{array}$ & 0.04 \\
\hline Horizon 6 & $\begin{array}{c}-0.753 \\
(0.731)\end{array}$ & $\begin{array}{l}-1.108 \text { * } \\
(0.598)\end{array}$ & 0.36 & $\begin{array}{l}-1.571 \\
(0.842)\end{array}$ & $\begin{array}{l}-1.860 \\
(0.751)\end{array}$ & 0.45 & $\begin{array}{r}0.011 \\
(0.828)\end{array}$ & $\begin{array}{l}-1.109 \\
(0.780)\end{array}$ & 0.06 \\
\hline Horizon 7 & $\begin{array}{r}-0.620 \\
(0.677)\end{array}$ & $\begin{array}{l}-0.863 \text { * } \\
(0.499)\end{array}$ & 0.59 & $\begin{array}{r}-0.900 \\
(0.749)\end{array}$ & $\begin{array}{l}-1.179 \\
(0.731)\end{array}$ & 0.49 & $\begin{array}{r}-0.220 \\
(0.871)\end{array}$ & $\begin{array}{l}-1.418 \text { * } \\
(0.852)\end{array}$ & 0.05 \\
\hline Adjusted $R^{2}$ & & 0.16 & & & 0.14 & & & 0.10 & \\
\hline Number of $\mathrm{C}$ ountries & & 120 & & & 115 & & & 115 & \\
\hline Number of 0 bservations & & 5,175 & & & 3,441 & & & 3,942 & \\
\hline
\end{tabular}

Source: IMF staff calculations.

Note: The table presents results from estimating equation (3) on a sample of countries with average annual temperature above $15^{\circ} \mathrm{C}$. In the regressions, indicators for policy measures are interacted with temperature, precipitation, and their lags, controlling for country and region-year fixed effects, lags of growth and policy measure, forwards of temperature and precipitation. Separate regressions are estimated for each horizon. Regression summary statistics are reported for horizon 0 . Standard errors reported in parenthesis are clustered at the country level.

${ }^{\star} p<0.1 ;{ }^{* \star} p<0.05 ;{ }^{* \star *} p<0.01$.

The short-term negative effects of temperature shocks tend to be larger in countries with lower buffers as evidenced by the larger estimated responses in columns (2), (5) and (8) in Table 2. However, the differences are typically not statistically significant, and in the few cases in which they are (fiscal buffers, foreign aid, and remittances), they tend to be very short-lived. Exchange rate regime, however, seems to be significantly associated with the extent of damage caused by weather shocks. Countries with non-pegged exchange rates tend to recover faster from these shocks. A similar pattern was documented by Ramcharan (2009), who finds that exchange rate flexibility helps economies adjust better in the aftermath of windstorms and earthquakes. 
Table 3. The Role of Structural Policies and Institutions

\begin{tabular}{|c|c|c|c|c|c|c|c|c|c|}
\hline \multirow{2}{*}{$\begin{array}{l}\text { Impact of a } 1^{\circ} \mathrm{C} \text { Increase in } \\
\text { Temperature on per } C \text { apita } 0 \text { utput }\end{array}$} & \multicolumn{3}{|c|}{ Domestic Financial Sector Reform Index } & \multicolumn{3}{|c|}{ International Finance R estrictions } & \multicolumn{3}{|c|}{ Human Capital } \\
\hline & High & Low & $\begin{array}{l}P \text {-value } \\
\text { P }\end{array}$ & Low & High & $P$-value & High & Low & 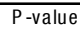 \\
\hline Horizon 0 & $\begin{array}{l}-1.540^{* * *} \\
(0.437)\end{array}$ & $\begin{array}{l}-1.631^{\text {*** }} \\
(0.439)\end{array}$ & 0.59 & $\begin{array}{l}-0.7666^{* *} \\
(0.293)\end{array}$ & $\begin{array}{l}-1.139^{* \star *} \\
(0.275)\end{array}$ & 0.07 & $\begin{array}{l}-1.039^{* * *} \\
(0.291)\end{array}$ & $\begin{array}{l}-1.152^{* \star *} \\
(0.349)\end{array}$ & 0.63 \\
\hline Horizon 1 & $\begin{array}{l}-1.539^{* * \star} \\
(0.518)\end{array}$ & $\begin{array}{l}-1.853^{* \star \star} \\
(0.598)\end{array}$ & 0.17 & $\begin{array}{l}-0.9066^{* *} \\
(0.391)\end{array}$ & 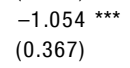 & 0.50 & $\begin{array}{l}-0.8911^{\star *} \\
(0.411)\end{array}$ & $\begin{array}{l}-1.250^{* * *} \\
(0.420)\end{array}$ & 0.25 \\
\hline Horizon 2 & $\begin{array}{l}-0.413 \\
(0.538)\end{array}$ & $\begin{array}{l}-0.923 \\
(0.711)\end{array}$ & 0.15 & $\begin{array}{l}-0.622 \\
(0.434)\end{array}$ & $\begin{array}{l}-1.090 * * \\
(0.472)\end{array}$ & 0.10 & $\begin{array}{l}-0.669 \\
(0.437)\end{array}$ & $\begin{array}{l}-1.092 \text { ** } \\
(0.494)\end{array}$ & 0.27 \\
\hline Horizon 3 & $\begin{array}{l}-0.964 \\
(0.712)\end{array}$ & $\begin{array}{l}-1.724 \text { ** } \\
(0.854)\end{array}$ & 0.06 & $\begin{array}{l}-1.0899^{\star *} \\
(0.462)\end{array}$ & $\begin{array}{l}-1.3599^{\star * *} \\
(0.487)\end{array}$ & 0.39 & $\begin{array}{l}-1.065 \text { ** } \\
(0.475)\end{array}$ & $\begin{array}{l}-1.250 \text { ** } \\
(0.491)\end{array}$ & 0.64 \\
\hline Horizon 4 & $\begin{array}{l}-0.325 \\
(0.829)\end{array}$ & $\begin{array}{l}-1.118 \\
(0.855)\end{array}$ & 0.10 & $\begin{array}{l}-1.6011^{* \star *} \\
(0.502)\end{array}$ & $\begin{array}{l}-1.757^{\star \star \star *} \\
(0.529)\end{array}$ & 0.69 & $\begin{array}{l}-1.3455^{* *} \\
(0.527)\end{array}$ & $\begin{array}{l}-1.686^{* \star \star} \\
(0.576)\end{array}$ & 0.49 \\
\hline Horizon 5 & $\begin{array}{l}-0.707 \\
(0.844)\end{array}$ & $\begin{array}{l}-1.561 \\
(0.868)\end{array}$ & 0.13 & $\begin{array}{l}-1.790 \text { ** } \\
(0.702)\end{array}$ & $\begin{array}{l}-2.180 \text { *** } \\
(0.761)\end{array}$ & 0.41 & $\begin{array}{l}-1.161 \\
(0.699)\end{array}$ & $\begin{array}{l}-1.590 \text { ** } \\
(0.704)\end{array}$ & 0.46 \\
\hline Horizon 6 & $\begin{array}{l}-0.644 \\
(0.805)\end{array}$ & $\begin{array}{l}-1.412 \text { * } \\
(0.807)\end{array}$ & 0.22 & $\begin{array}{l}-1.608 \text { *** } \\
(0.594)\end{array}$ & $\begin{array}{l}-1.868^{\star * *} \\
(0.615)\end{array}$ & 0.59 & $\begin{array}{l}-1.009 \\
(0.685)\end{array}$ & $\begin{array}{l}-1.689 * * \\
(0.724)\end{array}$ & 0.34 \\
\hline Horizon 7 & $\begin{array}{l}-0.071 \\
(0.888)\end{array}$ & $\begin{array}{l}-0.847 \\
(0.818)\end{array}$ & 0.27 & $\begin{array}{l}-1.525^{\star *} \\
(0.682)\end{array}$ & $\begin{array}{l}-1.975 \text { *** } \\
(0.718)\end{array}$ & 0.39 & $\begin{array}{l}-0.657 \\
(0.736)\end{array}$ & $\begin{array}{l}-1.236 \text { * } \\
(0.715)\end{array}$ & 0.44 \\
\hline Adjusted $R^{2}$ & \multicolumn{3}{|c|}{0.24} & \multicolumn{3}{|c|}{0.13} & \multicolumn{3}{|c|}{0.12} \\
\hline Number of $C$ ountries & \multicolumn{3}{|c|}{46} & \multicolumn{3}{|c|}{74} & \multicolumn{3}{|c|}{89} \\
\hline Number of 0 bservations & \multicolumn{3}{|c|}{1,455} & \multicolumn{3}{|c|}{3,434} & \multicolumn{3}{|c|}{4,582} \\
\hline Impact of a $1^{\circ} \mathrm{C}$ Increase in & \multicolumn{3}{|c|}{ Physical C apital } & \multicolumn{3}{|c|}{ Political Regime Index } & \multicolumn{3}{|c|}{ Inequality } \\
\hline Temperature on per $\mathrm{C}$ apita 0 utput & High & Low & $P$-value & High & Low & $P$-value & Low & High & P-value \\
\hline Horizon 0 & $\begin{array}{l}-0.773^{\star \star \star} \\
(0.294)\end{array}$ & $\begin{array}{l}-0.861^{\text {}} \\
(0.302)\end{array}$ & 0.66 & $\begin{array}{l}-1.370^{\star \star *} \\
(0.328)\end{array}$ & $\begin{array}{l}-1.4522^{\star \star \star} \\
(0.293)\end{array}$ & 0.73 & $\begin{array}{l}-1.336^{\star \star \star} \\
(0.431)\end{array}$ & $\begin{array}{l}-1.559^{\star \star \star} \\
(0.390)\end{array}$ & 0.07 \\
\hline Horizon 1 & $\begin{array}{l}-0.782 \text { * } \\
(0.405)\end{array}$ & $\begin{array}{l}-0.777 \text { * } \\
(0.423)\end{array}$ & 0.99 & $\begin{array}{l}-1.132 \text { *** } \\
(0.393)\end{array}$ & $\begin{array}{l}-1.392 \text { *** } \\
(0.367)\end{array}$ & 0.27 & $\begin{array}{l}-1.034 \text { * } \\
(0.580)\end{array}$ & $\begin{array}{l}-1.240 \text { ** } \\
(0.588)\end{array}$ & 0.26 \\
\hline Horizon 2 & $\begin{array}{l}-0.550 \\
(0.442)\end{array}$ & $\begin{array}{l}-0.690 \\
(0.459)\end{array}$ & 0.69 & $\begin{array}{l}-1.110 \text { *** } \\
(0.416)\end{array}$ & $\begin{array}{l}-1.729 \text { *** } \\
(0.433)\end{array}$ & 0.01 & $\begin{array}{l}-0.814 \\
(0.584)\end{array}$ & $\begin{array}{l}-1.024 \text { * } \\
(0.591)\end{array}$ & 0.35 \\
\hline Horizon 3 & $\begin{array}{l}-0.430 \\
(0.411)\end{array}$ & $\begin{array}{l}-0.820 \\
(0.497)\end{array}$ & 0.30 & $\begin{array}{l}-1.374 \text { *** } \\
(0.466)\end{array}$ & $\begin{array}{l}-1.929 * \star * \\
(0.464)\end{array}$ & 0.03 & $\begin{array}{l}-0.947 \\
(0.714)\end{array}$ & $\begin{array}{l}-1.386 \text { * } \\
(0.738)\end{array}$ & 0.09 \\
\hline Horizon 4 & $\begin{array}{l}-0.543 \\
(0.464)\end{array}$ & $\begin{array}{l}-1.175 \text { ** } \\
(0.573)\end{array}$ & 0.15 & $\begin{array}{l}-1.599 * * \star \\
(0.566)\end{array}$ & $\begin{array}{l}-2.0955^{\star \star *} \\
(0.601)\end{array}$ & 0.09 & $\begin{array}{l}-0.819 \\
(0.827)\end{array}$ & $\begin{array}{l}-1.391 \text { * } \\
(0.820)\end{array}$ & 0.06 \\
\hline Horizon 5 & $\begin{array}{l}-0.953 \\
(0.625)\end{array}$ & $\begin{array}{l}-1.677^{\text {** }} \\
(0.755)\end{array}$ & 0.17 & $\begin{array}{l}-1.587 \text { ** } \\
(0.671)\end{array}$ & $\begin{array}{l}-2.0444^{* * *} \\
(0.705)\end{array}$ & 0.15 & $\begin{array}{l}-0.699 \\
(0.899)\end{array}$ & $\begin{array}{l}-1.634 \text { * } \\
(0.877)\end{array}$ & 0.01 \\
\hline Horizon 6 & $\begin{array}{l}-0.381 \\
(0.586)\end{array}$ & $\begin{array}{l}-1.546 \text { ** } \\
(0.691)\end{array}$ & 0.09 & $\begin{array}{l}-1.416 \text { ** } \\
(0.679)\end{array}$ & $\begin{array}{l}-2.128 \text { *** } \\
(0.704)\end{array}$ & 0.06 & $\begin{array}{l}-1.061 \\
(0.930)\end{array}$ & $\begin{array}{l}-2.067^{\star *} \\
(0.913)\end{array}$ & 0.01 \\
\hline Horizon 7 & $\begin{array}{l}-0.548 \\
(0.645)\end{array}$ & $\begin{array}{l}-1.610 \text { * } \\
(0.815)\end{array}$ & 0.14 & $\begin{array}{l}-1.325 * \\
(0.751)\end{array}$ & $\begin{array}{l}-2.320 \\
(0.788)\end{array}$ & 0.02 & $\begin{array}{l}-0.233 \\
(1.060)\end{array}$ & $\begin{array}{l}-1.320 \\
(0.998)\end{array}$ & 0.01 \\
\hline Adjusted $R^{2}$ & & 0.13 & & & 0.10 & & & 0.28 & \\
\hline Number of C ountries & & 114 & & & 106 & & & 95 & \\
\hline Number of 0 bservations & & 3,905 & & & 5,056 & & & 1,798 & \\
\hline
\end{tabular}

Source: IMF staff calculations.

Note: The table presents results from estimating equation (3) on a sample of countries with average annual temperature above $15^{\circ} \mathrm{C}$. In the regressions, indicators for policy measures are interacted with temperature, precipitation, and their lags, controlling for country and region-year fixed effects, lags of growth and policy measure, forwards of temperature and precipitation. Separate regressions are estimated for each horizon. Regression summary statistics are reported for horizon 0 . In all specifications, standard errors are clustered at the country level.

${ }^{*} p<0.1 ;{ }^{* *} p<0.05 ;{ }^{* \star *} p<0.01$.

The evidence is somewhat more compelling for structural policies and country characteristics that are typically deemed important for easing sectoral reallocation of factors of production and structural transformation in general. Standard errors are again quite large, and it is often difficult to reject the hypothesis that policies do not have an effect, but the point estimates of the effect of temperature shocks in the outer horizons are substantially larger in columns (2), (5), and (8). This suggests that the medium-term adverse effect of a temperature increase appears to fade when domestic and international financial markets are better regulated, infrastructure is widely available, democratic institutions are strong, and the distribution of income is fairly even. This evidence is in line with findings in the literature on the role of policies in attenuating the effects of natural disasters.

Other possible adaptation strategies, mentioned in Figure 1, include migration and various financial instruments, such as private and sovereign insurance (e.g. crop insurance, 
catastrophe bonds). In IMF (2017), we discuss the role of financial markets in coping with weather shocks, the possible role of migration as a last resort for individuals to protect themselves from unfavorable weather pattern in warm climates, and provide case studies of specific successful adaptation strategies in low income countries.

\section{The Role of Development}

The level of development could directly influence countries' vulnerability to weather shocks (see, for example, Dell, Jones and Olken, 2012). For example, in higher income countries, most people live in housing well equipped to withstand even severe weather shocks, thanks to good thermal insulation and air-conditioning, storm windows, high quality roofs and foundations. More developed countries may have better government policies that we cannot measure well individually, which can help them better withstand weather shocks. Yet, despite its wide-reaching policy implications, compelling evidence on the extent to which the level of development helps protect countries against climate change is scarce. The scarcity of evidence is perhaps not surprising. Using country-level data, it is difficult to establish definitively whether advanced economies experience a smaller marginal effect of heat on macroeconomic performance, because so few of them have hot climates.

We present new analysis to help shed light on the role of development in potentially mitigating the macroeconomic implications of climate change. To do so, we leverage the fact that some of the larger advanced economies, such as the United States, span several climate zones. For example, while the average annual temperature in the U.S. state of Maine is about $7^{\circ} \mathrm{C}$, it is $21^{\circ} \mathrm{C}$ in Texas. This within-country geographic heterogeneity makes it possible to compare whether economic activity in the "hot" states or provinces of advanced economies responds in the same way to a temperature increase as it does in the "hot" states or provinces of emerging market and developing economies.

We thus combine subnational growth data from roughly 1,460 provinces and states across 79 countries from Gennaioli et al. (2014) with annual temperature and precipitation data at the same level of aggregation, and zoom in on the set of provinces and states with average temperature greater than $15^{\circ} \mathrm{C}$ (about 610 provinces and states). We estimate equation (3) with $p_{i, t}$ taking the value of 1 for states or provinces located in advanced economies. $p_{i, t}$ is also interacted with lag of growth, $\mu_{i}^{h}$ denote state or province fixed effects, and region-year fixed effects, $\theta_{r, t}^{h}$, are allowed to vary across advanced and non-advanced economies. Standard errors are clustered at the province level. Our goal here is simply to establish that the overall development level can indeed modify the relationship between weather shocks and GDP, without attempting to disentangle the specific channels in which this may take place. ${ }^{10}$

\footnotetext{
${ }^{10}$ Data constraints prevent us from identifying the precise channels through which development attenuates the link between weather and overall economic performance. Economic activity in hot areas in advanced economies
} 
Figure 5. The Role of Development: Evidence from Subnational Data

(Percent; years on $\mathrm{x}$-axis)

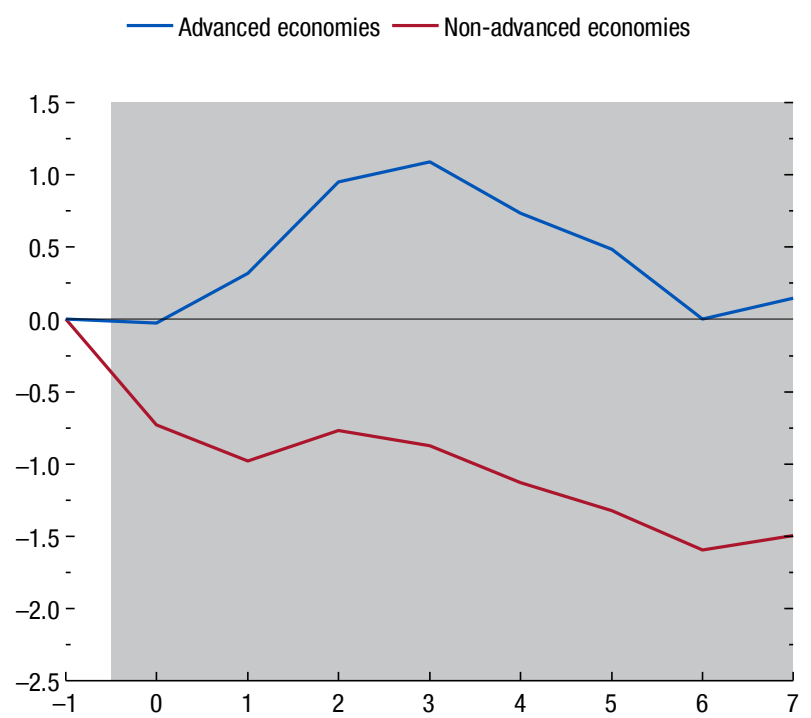

Source: IMF staff calculations.

Note: The figure depicts how the effect of a $1^{\circ} \mathrm{C}$ increase in temperature in the sample of states or provinces with average temperature exceeding $15^{\circ} \mathrm{C}$ varies with an indicator of whether the state or province is located in an advanced economy. Horizon 0 is the year of the shock. Gray area indicates that the blue and red lines are significantly different from each other at the 15 percent level.

The key results are presented in Figure 5 and Table 4. In column (1) of Table 4, we present

the impact of $1^{\circ} \mathrm{C}$ increase in temperature on per capita output at the subnational level for all 607 states and provinces with annual average temperature exceeding $15^{\circ} \mathrm{C}$. The subsequent columns of Table 4 present the estimated effects for subnational regions in advanced and non-advanced economies, as well as the p-value of a test of their difference. The analysis suggests that temperature shocks hurt hot areas in emerging market and developing economies significantly more than those in advanced economies (Figure 4). Thus, economic development seems, to some extent, to insulate countries from the vagaries of the weather.

\section{Historical Adaptation and Readiness for the Future}

Finally, we return to our initial country-level regressions to look for historical evidence of adaptation to weather shocks and reflect on the apparent readiness for different groups of countries to address weather shocks in the future. Despite some suggestive evidence on the effectiveness of policies for ameliorating these adverse shocks shown earlier and the positive

may be more insulated from temperature shocks since households exposed to these shocks have better access to ex post coping mechanisms (such as social protection) or have reduced their vulnerability to shocks through ex ante adaptation strategies (such as activity diversification, adoption of air-conditioning, higher quality housing, and the like). 
role of development, looking across countries, we do not find evidence of much adaptation over the past 60 years for a median low-income country.

We obtain the contemporaneous response of per capita output to temperature shocks by estimating equation (1) over rolling 20-year periods, and evaluating the effect using equation (2) for a median low-income developing country with an average annual temperature of 25 degrees Celsius. As shown in Figure 6, the relationship between the real per capita output and temperature has remained constant over time. In other words, any adaptation measures taken by countries were not enough to mute the effect of temperature shocks on GDP. ${ }^{11}$ This is an important finding, as studies reveal large differences in countries' ability
Figure 6. Effect of Temperature Increase on Real per Capita Output Estimated at the Temperature of the Median Low-Income Developing Country over Time (Percent; years on $\mathrm{x}$-axis)

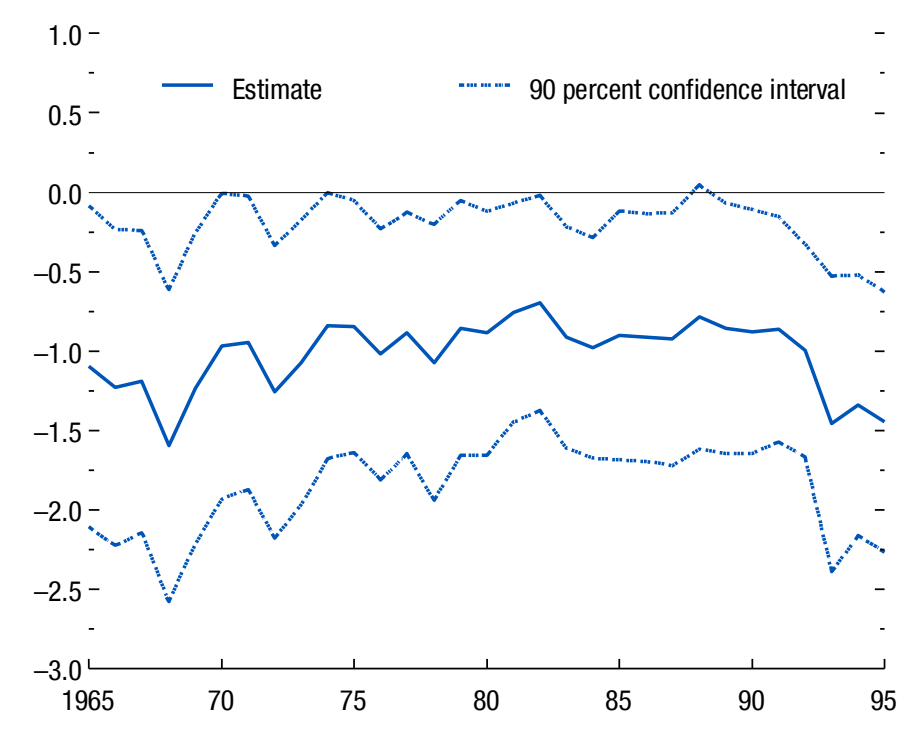

Source: IMF staff calculations.

Note: The figure depicts the effect of a $1^{\circ} \mathrm{C}$ increase in temperature at horizon 0 estimated at the median low-income developing country temperature $\left(25^{\circ} \mathrm{C}\right)$, over a 20 -year rolling window. Each point estimate is for a period $(t, t+20)$.

to adapt to specific weather shocks. For example, Hsiang and Narita (2012) and Hsiang and Jina (2014) find that countries more frequently exposed to tropical cyclones experience less damage, which suggests that they have learned to cope with these extreme events. Mortality caused by high temperatures has declined significantly over time with the introduction of airconditioning in the United States (Barreca et al. 2016). But there is little evidence of declining sensitivity of agricultural yields (Burke and Emerick 2016) or overall output (Deryugina and Hsiang 2014; Burke, Hsiang, and Miguel 2015; Dell, Jones, and Olken 2012) to temperature fluctuations.

The reasons behind this apparent lack of overall adaptation, especially in low income countries that suffer the most severe negative shocks, are not well understood. High costs, limited access to credit for financing adaptation, insufficient information about the benefits of adaptation, limited rationality in planning for future risks, and inadequate access to technology are likely constraints, as discussed in Carleton and Hsiang (2016).

\footnotetext{
${ }^{11}$ In Figure 6, we focus on low income countries which are on average very warm, but the contemporaneous response of GDP per capita to weather shocks also has not changed much over time for advanced economies or emerging markets.
} 
Moreover, low-income countries also often lack the institutional setting, administrative capacity, or political stability to implement appropriate macroeconomic policies or adaptation strategies. The Notre Dame Global Adaptation Index, shown in Figure 7, measures each country's readiness and capacity to adapt to weather shocks, and is based on 45 indicators which measure the quality/availability of food, water, health services, ecosystem services, infrastructure, etc. Using this metric, there is evidence that low income countries, i.e. those that have the greatest need to adapt to weather shocks, are indeed least prepared to do so. These findings further underscore the need for action at the global level to support low income countries' adaptation to weather shocks, as well as support global efforts to reduce emissions of greenhouse gases that contribute to global warming.

\section{Model-BASEd AnAlysis}

Figure 7. Vulnerability to Temperature Increase and Adaptation Prospects

- Low-income developing countries

Emerging market economies

- Advanced economies
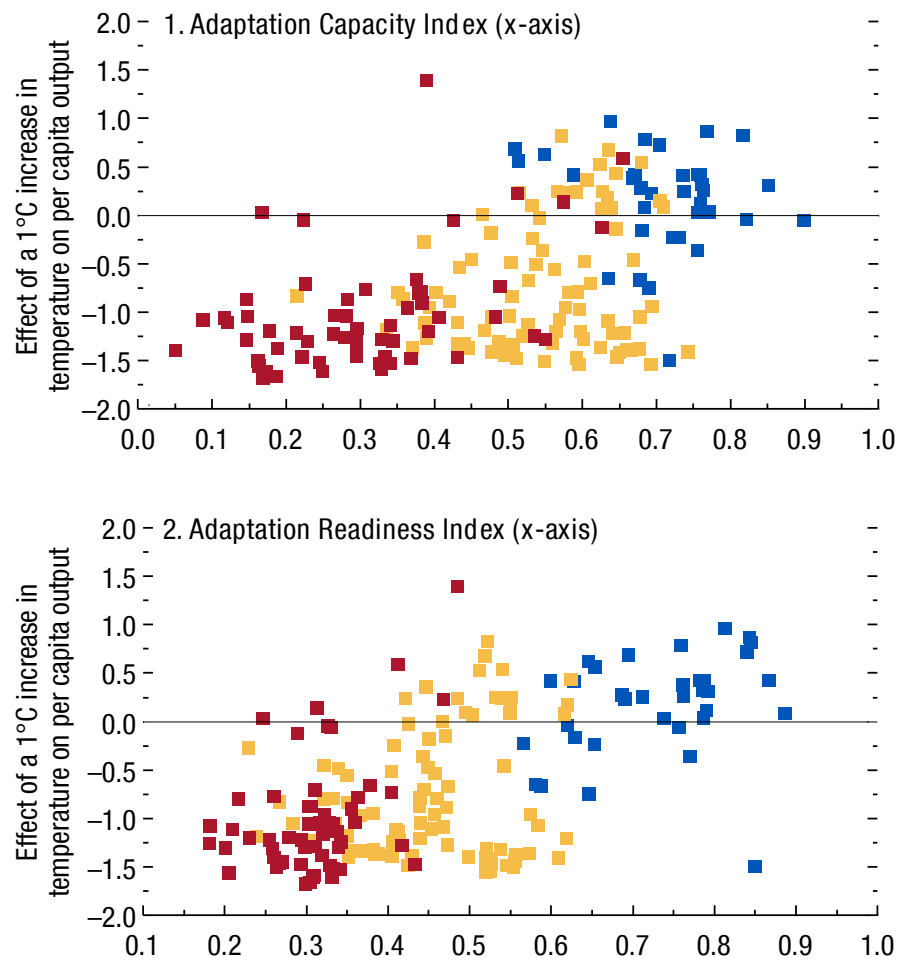

Sources: Notre Dame Global Adaptation Index; and IMF staff calculations. Note: The figure depicts the estimated effect of a $1^{\circ} \mathrm{C}$ increase in temperature on per capita output at horizon 0 against countries' score for adaptation readiness and adaptation capacity. A higher score indicates better adaptation capacity and more readiness.

To complement the empirical investigations discussed so for, in this section we use the Debt, Investment and Growth (DIG) model developed by Buffie et al. (2012) to illustrate how policies can help moderate the consequences of weather shocks in low-income countries. The model simulates the macroeconomic effects of temperature increases under various assumptions for key policy variables and compares them to a baseline effect of an increase in temperature in the absence of these policies. The main advantage of the model-based approach is that it allows us to precisely isolate the role of specific policies and trace the channels through which these operate at a conceptual level; something that is very difficult to achieve in a cross-country empirical analysis.

The DIG model is a dynamic general equilibrium model of a small open economy with an extensive fiscal component. Agents in the model optimize their lifetime utilities subject to intertemporal budget constraints and with perfect foresight. The production side of the model has two sectors that use public and private capital as input. Many features of the model are specifically geared towards low-income countries, such as low public investment efficiency, 
limited fiscal space, and high capital adjustment costs. The analysis calibrates the model so that the weather-induced damage to output —-through shocks to total factor productivity and investment in productive capital—broadly matches the estimated response of GDP to a $1^{\circ} \mathrm{C}$ increase in temperature in a representative low-income country. (A representative lowincome country has a baseline temperature of $25^{\circ} \mathrm{C}$, same as in the earlier empirical section.) In other words, after the weather shocks hits in the initial period, output declines due to a reduction in total factor productivity and some destruction of productive capital. By using model-based experiments, we examine the extent to which these damages may be mitigated by macroeconomic and structural policies.

\section{A. Description of the model and parameters}

The DIG model has served as a workhorse in many IMF studies of low-income countries. It is an optimizing intertemporal model with perfect foresight. It describes a small open economy model with a tradeable and non-tradeable sector of production. Public capital is productive (as it enters private firms' production function) in both sectors. Government spending can raise output directly by augmenting the stock of public capital, but it can also crowd in as well as crowd out private investment.

In both sector, firms' technologies adhere to the standard Cobb-Douglas functional form. Firms combine labor, private capital, and public capital (i.e. infrastructure) to produce output. ${ }^{12}$ The evolution of total factor productivity (TFP) is exogenous in both sectors. Profit maximizing firms face separate prices for exports and imports.

Consumers (households) supply labor and derive utility from consuming the domestic traded good, the foreign traded good, and the domestic nontraded good. These goods are combined into a constant elasticity of substitution basket. The model breaks Ricardian equivalence by including both savers and hand-to-mouth consumers in fixed proportions. Only savers maximize the present value of their lifetime utility through intertemporal maximization.

The government spends on transfers, debt service, and (partially inefficient) infrastructure investment. It collects revenue from a consumption value-added tax (VAT) and from user fees for infrastructure services. The government deficit is financed through domestic and external borrowing, where external borrowing can be concessional or commercial borrowing. Policymakers accept all concessional loans offered by official creditors. The borrowing and amortization schedule for these loans is fixed exogenously. Debt sustainability requires that, in the case of a deficit, the VAT and transfers eventually adjust to cover the entire deficit, given the exogenously determined upper limit on taxes and lower limit on transfers. In other words, the model admits no sovereign default. The model incorporates shocks to the government external debt risk premium (or world interest rates).

\footnotetext{
${ }^{12}$ For simplicity, the traded and nontraded sectors are assumed to react equally to weather shocks. The findings are robust to this modeling choice.
} 
The majority of the model parameters are set to the same values as in Buffie et al. (2012), with few exceptions, mostly to reflect the decline in global interest rates since the global financial crisis, the projection of trend GDP growth in low-income countries, and the sample median of public-debt-to-GDP ratios. The parameters that differ from the ones in Buffie et al. (2012) are presented in Table 5.

Table 5. Parameterization of the Debt, Investment, and Growth Model

\begin{tabular}{lc}
\hline \multicolumn{1}{c}{ Parameter } & $\begin{array}{c}\text { Value } \\
\text { (percent) }\end{array}$ \\
\hline Initial Return on Infrastructure Investment & 30 \\
Public Domestic Debt-to-GDP Ratio & 10 \\
Public Concessional Debt-to-GDP Ratio & 30 \\
Public External Commercial Debt-to-GDP Ratio & 5 \\
Oil Revenues-to-GDP Ratio & 2 \\
Real Interest Rate on Public Domestic Debt & 7 \\
Real Interest Rate on Public External Commercial Debt & 4 \\
Trend per Capita Growth Rate & 2.8 \\
\hline
\end{tabular}

Sources: Buffie et al. (2012); and authors' calculations.

As regards weather shocks, the model is calibrated so that the shape of the trajectory of output (and the maximum decline of the output) in the model broadly follows the trajectory of estimated GDP per capita if the temperature shock equals $1^{\circ} \mathrm{C}$.

\section{B. The Role of Domestic Policies and Institutions: Model Simulations}

As discussed in Section III, weather shocks can weigh significantly on the economic output and public finances in low-income countries. Government revenues can be adversely affected by the reduction in aggregate output, while spending may need to be ramped up to deliver support to affected households if weather shocks compromise food security; rebuild transport or communication infrastructure if they are damaged by natural disasters; and potentially retrain the workforce if weather shocks result in permanent displacement of certain types of labor.

We explore the role of three sets of policies through model simulations, namely, the availability of fiscal space at the time of the shock, which can be augmented through transfers from advanced economies, the efficiency of public spending, and the speed and ease with which factors of production can be reallocated across sectors in the aftermath of a weather shock.

Model simulations suggest that having fiscal space can significantly limit the damage from weather shocks to output. Since fiscal space is often tight in many low-income countries, we proxy fiscal space by additional transfers from advanced economies (such as those agreed to in the Paris Agreement) to build up public investment for three years, starting a year after the weather shock (Figure 8, panel 2). Additional transfers of 1 percent of the recipient country's 
GDP reduce the depth of the recession by about 0.5 percent throughout the simulation period. ${ }^{13}$ These transfers increase the stock of public infrastructure, thereby boosting productive capacity in both the traded and non-traded sector. Encouragingly, in the model these fiscal transfers increase output not only in the short term, but also in the long term, thanks to a resulting increase in the stock of public infrastructure. The model finding about the role of fiscal space is consistent with earlier empirical evidence that countries with low public debt, high foreign aid and high remittances (Figure 3, panels 1, 4, and 5) may experience smaller weather-related output losses.

Structural policies and institutions play important roles as well. For example, the efficiency of investment in public sector infrastructure, and the quality of public sector governance in general, will determine the benefits of any fiscal transfers or foreign grants. Efficiency of public investment is low in many low-income countries, with estimates of the share of public infrastructure spending that truly increases the stock of public capital ranging from the low efficiency of 20 percent to average efficiency of 60 percent (Foster and BricenoGarmendia 2010; Hulten 1996; Pritchett 2000). (Perfect public sector efficiency would imply that every dollar spent increases public capital by one dollar.)

Model simulations in Figure 8, panel 3, show that in countries with high public investment efficiency, the receipt of additional transfers of 1 percent of GDP can effectively dampen the adverse consequences of a weather shock. In countries with low public investment efficiency, however, there is little difference between receiving and not receiving these high additional transfers, since additional received funds are
Figure 8. The Role of Policies: A ModelBased Analysis

(Real GDP, deviation from steady state; years on $\mathrm{x}$-axis)

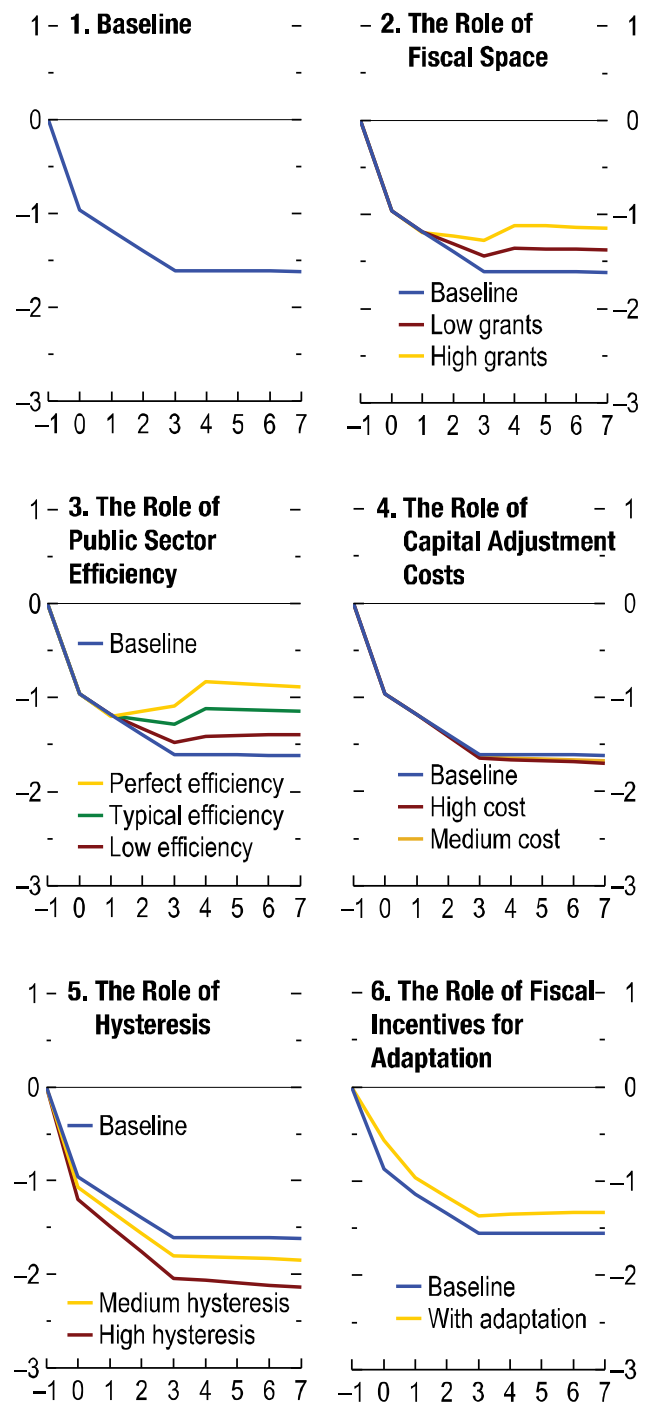

Source: IMF staff calculations. Note: In panel 1, the baseline presents the deviation from steady state in real GDP resulting from a $1^{\circ} \mathrm{C}$ increase in temperature in a representative low-income country with an average annual temperature of $25^{\circ} \mathrm{C}$. In other panels, the baseline assumes no additional grants in panels 2 and 3 , low adjustment cost in panel 4 , no hysteresis in panel 5 , and no adaptation in panel 6 . In panel 2, additional grants amount to 0.5 percent of GDP in low grants scenario, and 1 percent of GDP in high grants scenario. In panel 3 , all simulations, except the baseline, assume high additional grants.

\footnotetext{
${ }^{13}$ With the baseline concessional debt equal to 30 percent of GDP, these one-time increases in transfers are not overwhelmingly large, but are significant in the short run.
} 
wasted and not transformed into productive infrastructure. In sum, the simulation shows convincingly that low-income countries must keep improving the efficiency of public investment and strengthening their institutional frameworks to reap the full benefit of having buffers to counteract the effects of changing weather conditions. These model simulations are again consistent with earlier empirical evidence presented in Figure 4, panel 5, which showed that countries with better governance (i.e. higher polity score) suffer smaller weather-related damages to per capita output.

Weather shocks, as well as long-lasting changes in climate, can disrupt production in certain sectors of the economy, such as agriculture in certain regions. Adjusting to these shocks requires reallocating workers and capital away from these specific sectors. The speed and cost at which factors of production can be reallocated influences the speed of economic recovery after adverse weather-related shocks reduce the total factor productivity and/or the stock of capital. In low-income countries, reallocation of capital (and factors of production in general) can be hampered by rigid economic environments and suboptimal policies, for example, limited access to financial markets, bureaucratic impediments such as difficulties in obtaining building permits, and legal uncertainties. ${ }^{14}$

Model simulations indicate that higher costs of capital reallocation slow the recovery from weather shocks (Figure 8, panel 4). The quantitative impact of adjustment costs of typical magnitude for a low-income country appears small, but the simulation should be seen as a qualitative guide only. The size of the GDP decline depends on the cost of capital adjustment as well as on the shape and timing of the shock. If the climate shock results mostly in the destruction of private capital and to a lesser extent in lowering total factor productivity, then the recovery is slower and damage to GDP larger. ${ }^{15}$ In this case too, model simulations are consistent with earlier empirical evidence. For example, in Figure 4, panel 1, we saw that countries with high financial sector liberalization, and thus likely lower capital adjustment costs, experience smaller output losses due to weather shocks than countries with low financial sector liberalization.

Finally, the speed at which affected workers can be reallocated to alternative productive activities also matters (Figure 8, panel 5). Unemployment can cause hysteresis or permanent "scarring” of productivity, since workers lose skills during long spells of unemployment or underemployment. In the DIG framework, this channel is captured in the sensitivity of

\footnotetext{
${ }^{14}$ In the DIG model, the ease of factor reallocation is captured in the cost of private capital adjustment parameter. The cost of capital adjustment is inversely proportional to elasticity of investment with respect to Tobin's q, in which higher elasticity implies lower capital adjustment costs.

15 This is because in the model the rebuilding of capital is a slower process than the rebound of total factor productivity.
} 
productivity to lagged negative output gaps. ${ }^{16}$ The results from simulations that vary this sensitivity suggest that hysteresis could significantly prolong and deepen the effects of weather shocks. Hence, policies should aim to preserve human capital, including by instituting programs that provide incentives to the unemployed to participate in humancapital-preserving activities, such as public works projects, as in the Ethiopian Productive Safety Net Program (see IMF 2017).

\section{Investment in Adaptation Strategies}

In addition to the typical macroeconomic and structural policies discussed above, governments, households, and firms also engage in direct investments to adapt to changing weather conditions (for example, by planting more-heat-resistant crops or investing in green infrastructure). Many adaptation measures, however, have the nature of public goods. Setting up an early-warning system for extreme heat, instituting information campaigns about water conservation, increasing vegetation in public areas and other green infrastructure investments can have nonrival and nonexcludable payoffs. Because households and firms are unable to internalize the full social benefits, government involvement may typically be needed to provide incentives to private agents to undertake adaptation efforts toward the socially optimal levels.

We do not have good cross-country data available on investment in different adaptation strategies. This is because adaptation strategies are often country-specific, and because some countries have only recently started exploring and implementing such measures. Hence, our empirical work on adaptation was limited. We could only indirectly examine whether countries were successful at adapting to climate change, with the assumption that -if they are successful-weather shocks would show reduced impact on output. In our empirical work, we found no evidence of successful adaptation in the aggregate, since the response of output per capita to weather shocks remained similar over time (see Section III.D).

Model simulations allow us to directly explore the extent to which climate adaptation strategies could help mitigate the negative effect of weather on output. In an extension of the DIG model described in Annex 2, the government introduces fiscal incentives for the adoption of resilience-improving technologies by private agents. Assuming that private adaptation expenditure falls 20 percent short of the social optimum, the government provides subsidies to restore optimality.

Simulations suggest that over 20 years, each $\$ 1$ spent on adaptation subsidies by the government reduces aggregate weather damage by $\$ 2$. The mechanism behind this finding is that private investment responds to the reduced weather-related productivity losses, which boosts GDP in the medium and long term. The simulation illustrates a general principle that

\footnotetext{
${ }^{16}$ The size of the effect is calibrated by using the estimated elasticity of current wages to lagged hours worked by Altuğ and Miller (1998). Their estimated elasticity of 0.2 stands for the high degree of hysteresis in the model specification.
} 
improving resilience through public support of private investment in adaptation can reduce weather-driven downturns and accelerate recoveries (Figure 8, panel 6).

\section{ConClusion}

Our paper offers new evidence on the extent to which policies-macroeconomic policies, structural policies, institutions, as well as climate adaptation policies_-can help countries cope with negative weather shocks. Our findings are both encouraging and alarming.

Encouragingly, we find that policies do help mitigate the negative effects of weather shocks on output. This is confirmed in both our empirical work and model simulations. Our empirical analysis shows that fiscal buffers, as captured in having low public debt, high foreign aid, or support through high remittances, can all help reduce the negative effect of temperature increases on output. Structural policies, such as high financial sector liberalization, low capital account restrictions, good infrastructure, and a high polity score, can also contribute to mitigating the negative effect of the weather. Our model simulations show that climate adaptation investment can reduce the negative effect of temperature increases on output.

However, alarmingly, the magnitudes of the estimated effects of various adaptation policies -in both our empirical work and in the model simulations - are quite small. None of the specific policies that we identify are sufficient to completely erase the negative effect of an increase in temperature shock on output. Instead, these policies typically offer a marginal (though statistically significant) improvement over the case of no such supportive policies. Of course, specific adaptation strategies can be very effective at the micro-level, such as introduction of air-conditioning which has reduced heat-related mortality (Deschênes and Greenstone 2011, Barreca et al. 2016). But looking at the aggregate effects, at the country level, it does not seem that countries have found a way to adapt successfully.

The only exception to this general pattern comes from our empirical analysis using subnational data, which suggests that a higher level of overall development is associated with a smaller negative effect of an increase in temperature. This finding suggests that advanced countries have somehow found ways to better insulate their "hot" regions from negative effects of temperature. We cannot identify the specific ways in which these "hot" regions have adapted to their climates, but this finding offers some hope for effectiveness of climate adaptation strategies.

Taken together, our findings suggest that climate adaptation strategies are likely to have limited success in low-income countries in the near future. Low-income countries tend to have low capacity for climate adaptation, and they also have low public sector efficiency, both of which make it less likely that climate adaptation strategies would be successful in mitigating the impact of rising temperatures. However, many good policies that can help attenuate the negative effects of weather shocks, such as low public debt or exchange rate 
flexibility, also tend to be beneficial for other reasons too. The fact that they also help countries recover from weather shocks more quickly are just an additional reason to pursue these good macroeconomic policies.

Finally, our findings underscore the need for greater international commitment to climate change mitigation, which would limit greenhouse gas emissions going forward, and thus limit further global temperature increases. Low-income countries have historically emitted negligible quantities of greenhouse gases, compared to advanced economies and some emerging markets (see IMF 2017). Yet, low-income countries with high average annual temperatures are suffering the most from rising temperatures, and their prospects for successful adaptation to climate change are limited. Helping low-income countries cope with the consequences of climate change is both a moral duty and sound global economic policy that helps offset countries' failures to fully internalize the costs of greenhouse gas emissions. 


\section{REFERENCES}

Abiad, Abdul, Enrica Detragiache, and Thierry Tressel. 2008. “A New Database of Financial Reforms.” IMF Working Paper 08/266, International Monetary Fund, Washington, DC.

Acevedo Mejia, Sebastian, Mico Mrkaic, Natalija Novta, Evgenia Pugacheva, and Petia Topalova. 2018. “The Effects of Weather Shocks on Economic Activity: What are the Channels of Impact?” IMF Working Paper 18/144, International Monetary Fund, Washington, DC.

Altuğ, Sumru, and Robert A. Miller. 1998. "The Effect of Work Experience on Female Wages and Labour Supply.” Review of Economic Studies 65 (1): 45-85.

Barreca, Alan, Karen Clay, Olivier Deschenes, Michael Greenstone, and Joseph S. Shapiro. 2016. "Adapting to climate change: The remarkable decline in the US temperature-mortality relationship over the twentieth century." Journal of Political Economy 124 (1): 105-159.

Breckner, Miriam, Florian Englmaier, Till Stowasser, and Uwe Sunde. 2016. “Economic Development and Resilience to Natural Catastrophes-Insurance Penetration and Institutions.” Unpublished.

Buffie, Edward, Andrew Berg, Catherine Pattillo, Rafael Portillo, and Luis-Felipe Zanna. 2012. "Public Investment, Growth, and Debt Sustainability: Putting Together the Pieces.” IMF Working Paper 12/144, International Monetary Fund, Washington, DC.

Burgess, Robin, Olivier Deschênes, Dave Donaldson, and Michael Greenstone. 2014. “The Unequal Effects of Weather and Climate Change: Evidence from Mortality in India.” Unpublished.

Burke, Marshall and Kyle Emerick. 2016. “Adaptation to Climate Change: Evidence from US Agriculture.” American Economic Journal: Economic Policy 8 (3): 10640 .

Burke, Marshall, Solomon M. Hsiang, and Edward Miguel. 2015. “Global Non-Linear Effect of Temperature on Economic Production.” Nature 527: 235-39.

Burke, Marshall B., Edward Miguel, Shanker Satyanath, John A. Dykema, and David B. Lobell. "Warming increases the risk of civil war in Africa." Proceedings of the national Academy of sciences 106, no. 49 (2009): 20670-20674. 
Cabezon, Ezequiel, Leni Hunter, Patrizia Tumbarello, Kazuaki Washimi, and Yiqun Wu. 2015. "Enhancing Macroeconomic Resilience to Natural Disasters and Climate Change in the Small States of the Pacific.” IMF Working Paper 15/125, International Monetary Fund, Washington, DC.

Calderón, César, Enrique Moral-Benito, and Luis Servén. 2015. "Is Infrastructure Capital Productive? A Dynamic Heterogeneous Approach.” Journal of Applied Econometrics 30 (2): 177-98.

Carleton, Tamma A, and Solomon M. Hsiang. 2016. "Social and Economic Impacts of Climate.” Science 353 (6304).

Cavallo, Edurardo, Sebastian Galiani, Ilan Noy, and Juan Pantano. 2013. "Catastrophic Natural Disasters and Economic Growth.” Review of Economics and Statistics 95 (5): 1549-61.

Chen, Chen, Ian Noble, Jessica Hellmann, Joyce Coffee, Martin Murillo, and Nitesh Chawla. 2015. University of Notre Dame Global Adaptation Index. Country Index Technical Report.

Costinot, Arnaud, Dave Donaldson, and Cory Smith. "Evolving comparative advantage and the impact of climate change in agricultural markets: Evidence from 1.7 million fields around the world." Journal of Political Economy 124.1 (2016): 205-248.

Dell, Melissa, Benjamin F. Jones, and Benjamin A. Olken. 2012. "Temperature Shocks and Economic Growth: Evidence from the Last Half Century.” American Economic Journal: Macroeconomics 4 (3): 66-95.

Deryugina, Tatyana. 2011. "The Role of Transfer Payments in Mitigating Shocks: Evidence from the Impact of Hurricanes.” Munich Personal RePEc Archive (MPRA) Paper 53307, Munich.

—_ and Solomon M. Hsiang. 2014. "Does the Environment Still Matter? Daily Temperature and Income in the United States.” NBER Working Paper 20750, National Bureau of Economic Research, Cambridge, MA.

Deschênes, Olivier, and Michael Greenstone. 2011. "Climate change, mortality, and adaptation: Evidence from annual fluctuations in weather in the US." American Economic Journal: Applied Economics 3.4: 152-85.

Farid, Mai, Michael Keen, Michael Papaioannou, Ian Parry, Catherine Pattillo, and Anna Ter-Martirosyan. 2016. “After Paris: Fiscal, Macroeconomic, and Financial 
Implications of Climate Change.” IMF Staff Discussion Note 16/01, International Monetary Fund, Washington, DC.

Felbermayr, Gabriel, and Jasmin Gröschl. 2014. "Naturally Negative: The Growth Effects of Natural Disasters.” Journal of Development Economics 111: 92-106.

Foster, Vivien, and Cecilia Briceno-Garmendia. 2010. Africa's Infrastructure: A Time for Transformation. Africa Development Forum. World Bank, Washington, DC.

Gennaioli, Nicola, Rafael La Porta, Florencio Lopez De Silanes, and Andrei Shleifer. 2014. “Growth in Regions.” Journal of Economic Growth 19 (3): 259-309.

Hallegatte, Stéphane. 2009. “Strategies to Adapt to an Uncertain Climate Change.” Global Environmental Change 19(2): 240-47.

—_ Franck Lecocq, and Christian de Perthuis. 2011. "Designing Climate Change Adaptation Policies: An Economic Framework.” Policy Research Working Paper 5568, World Bank, Washington, DC.

Mook Bangalore, Laura Bonzanigo, Marianne Fay, Tamaro Kane, Ulf Narloch, Julie Rozenberg, David Treguer, and Adrien Vogt-Schilb. 2016. "Shock Waves: Managing the Impacts of Climate Change on Poverty.” Climate Change and Development Series. World Bank, Washington, DC.

Heal, Geoffrey, and Jisung Park. Feeling the heat: Temperature, physiology \& the wealth of nations. No. w19725. National Bureau of Economic Research, 2013.

Huq, Saleemul, Hannah Reid, Mama Konate, Atiq Rahman, Youba Sokona, and Florence Crick. "Mainstreaming adaptation to climate change in least developed countries (LDCs)." Climate Policy 4, no. 1 (2004): 25-43.

Hsiang, Solomon M., and Daiju Narita. 2012. “Adaptation to Cyclone Risk: Evidence from the Global Cross-Section.” Climate Change Economics 3 (2).

— Run Economic Growth: Evidence from 6,700 Cyclones.” NBER Working Paper 20352, National Bureau of Economic Research, Cambridge, MA.

Hulten, Charles R. 1996. "Infrastructure Capital and Economic Growth: How Well You Use It May Be More Important Than How Much You Have.” NBER Working Paper 5847, National Bureau of Economic Research, Cambridge, MA.

Ilzetzki, Ethan, Carmen M. Reinhart, and Kenneth S. Rogoff. 2008. "Exchange Rate Arrangements Entering the 21st Century: Which Anchor Will Hold?” NBER 
Working Paper 23134, National Bureau of Economic Research, Cambridge, MA.

International Monetary Fund (IMF). 2016a. "Enhancing Resilience to Natural Disasters in Sub-Saharan Africa.” In Regional Economic Outlook: Sub-Saharan Africa. Washington DC, October.

— 2016b. “Small States' Resilience to Natural Disasters and Climate Change: Role for the IMF.” Board Paper, Washington, DC.

—. 2017. "The Effects of Weather Shocks on Economic Activity: How Can LowIncome Countries Cope?” Chapter 3 of the October 2017 World Economic Outlook. Washington, DC.

Intergovernmental Panel on Climate Change (IPCC). 2014. "Climate Change 2014: Impacts, Adaptation, and Vulnerability. Part A: Global and Sectoral Aspects.” Contribution of Working Group II to the Fifth Assessment Report of the Intergovernmental Panel on Climate Change. Cambridge, United Kingdom and New York, NY: Cambridge University Press.

Jordà, Òscar. 2005. "Estimation and Inference of Impulse Responses by Local Projections.” American Economic Review 95 (1): 161-82.

Kahn, Matthew. 2005. “The Death Toll from Natural Disasters: The Role of Income, Geography and Institutions.” Review of Economics and Statistics 87 (2): 27184.

Klein Goldewijk, Kees, Arthur Beusen, Jonathan Doelman, and Elke Stehfest. 2016. "New Anthropogenic Land Use Estimates for the Holocene; HYDE 3.2.” Earth System Science Data.

Lane, Philip R., and Gian Maria Milesi-Ferretti. 2017. “International Financial Integration in the Aftermath of the Global Financial Crisis.” IMF Working Paper 17/115, International Monetary Fund, Washington, DC.Reinhart, Carmen, and Kenneth S. Rogoff. 2004. "The Modern History of Exchange Rate Arrangements: A Reinterpretation.” Quarterly Journal of Economics 119 (1): $1-48$.

Lee, Minsoo, Mai Lin Villaruel, and Raymond Gaspar. 2016. "Effects of Temperature Shocks on Economic Growth and Welfare in Asia.” ADB Economics Working Paper 501, Asian Development Bank, Mandaluyong City, Philippines. 
McDermott, Thomas K. J., Frank Barry, and Richard S. J. Tol. 2013. “Disasters and Development: Natural Disasters, Credit Constraints, and Economic Growth.” Oxford Economic Papers 66 (3): 750-73.

McKibbin, Warwick J., and Peter J. Wilcoxen. Climate policy and uncertainty: the roles of adaptation versus mitigation. Washington, DC: Brookings Institution, 2004.

Noy, Ilan. 2009. “The Macroeconomic Consequences of Disasters.” Journal of Development Economics 88 (2): 221-31.

Organisation for Economic Co-operation and Development (OECD). 2015. Climate Change Risks and Adaptation: Linking Policy and Economics. Paris: OECD Publishing.

Pritchett, Lant. 2000. "The Tyranny of Concepts: CUDIE (Cumulated, Depreciated, Investment Effort) Is Not Capital.” Journal of Economic Growth 5 (4): 36184.

Quinn, Dennis P. 1997. “The Correlates of Change in International Financial Regulation.” American Political Science Review 91 (3): 531-51.

— Growth?” Review of Financial Studies 21 (3): 1403-49.

Raddatz, Claudio. 2009. “The Wrath of God: Macroeconomic Costs of Natural Disasters.” Policy Research Working Paper 5039, World Bank, Washington, DC.

Ramcharan, Rodney. 2009. "Does the Exchange Rate Regime Matter for Real Shocks? Evidence from Windstorms and Earthquakes.” Journal of International Economics 73 (1): 31-47.

Ranson, Matthew. "Crime, weather, and climate change." Journal of environmental economics and management 67, no. 3 (2014): 274-302.

Reinhart, Carmen, and Kenneth S. Rogoff. 2004. "The Modern History of Exchange Rate Arrangements: A Reinterpretation.” Quarterly Journal of Economics 119 (1): $1-48$.

Sinha, Paramita, and Maureen L. Cropper. The value of climate amenities: Evidence from US migration decisions. No. w18756. National Bureau of Economic Research, 2013.

Teulings, Coen N., and Nikolay Zubanov. 2014. "Is Economic Recovery a Myth? Robust Estimation of Impulse Responses.” Journal of Applied Econometrics 29 (3): 497-514. 
Von Peter, Goetz, Sebastian V. Dahlen, and Sweta Saxena. 2012. "Unmitigated Disasters? New Evidence on the Macroeconomic Cost of Natural Catastrophes.” BIS Working Paper 394, Bank for International Settlements, Basel.

Weitzman, Martin. 2011. "Fat-Tailed Uncertainty in the Economics of Catastrophic Climate Change.” Review of Environmental Economics and Policy 5(2): 275-92. 
VII. ANNEX

\section{Annex 1. Data Sources and Country Groupings}

\section{Annex Table 1. Data Sources}

\begin{tabular}{|c|c|}
\hline Indicator & Source \\
\hline $\begin{array}{l}\text { Temperature and Precipitation, } \\
\text { Historical (Grid Level) }\end{array}$ & University of East Anglia, Climate Research Unit (CRU TS v.3.24) \\
\hline Population 1950 (Grid Level) & $\begin{array}{l}\text { History Database of the Global Environment (HYDE v3.2); Klein } \\
\text { et al. (2016) }\end{array}$ \\
\hline Real GDP per Capita & $\begin{array}{l}\text { IMF, World Economic Outlook database; World Bank, World } \\
\text { Development Indicators database }\end{array}$ \\
\hline Subnational GDP per Capita & Gennaioli et al. (2014) \\
\hline Consumer Price Index & IMF, World Economic Outlook database \\
\hline Debt-to-GDP Ratio & IMF, Historical Public Debt Database \\
\hline Reserves Minus Gold & $\begin{array}{l}\text { Lane and Milesi-Ferretti (2017), External Wealth of Nations } \\
\text { database updated to } 2015\end{array}$ \\
\hline $\begin{array}{l}\text { Net Official Development Assistance } \\
\text { and Official Aid Received }\end{array}$ & World Bank, World Development Indicators database \\
\hline Personal Remittances Received & World Bank, World Development Indicators database \\
\hline Exchange Rate Regime Indicator & $\begin{array}{l}\text { Reinhart and Rogoff (2004); Ilzetzki, Reinhart, and Rogoff (2008), } \\
\text { updated to } 2015\end{array}$ \\
\hline Adaptation Readiness and Capacity & $\begin{array}{l}\text { Notre Dame Global Adaptation Initiative (ND-GAIN), Chen et al. } \\
\text { (2015) }\end{array}$ \\
\hline $\begin{array}{l}\text { Domestic Financial Sector } \\
\text { Liberalization Index }\end{array}$ & Abiad, Detragiache, and Tressel (2008) \\
\hline Quinn-Toyoda Capital Control Index & Quinn (1997); Quinn and Toyoda (2008) \\
\hline Human Capital Index & Penn World Tables 9.0 \\
\hline Paved Roads Kilometers per Capita & $\begin{array}{l}\text { Calderón, Moral-Benito, and Servén (2014); World Bank, World } \\
\text { Development Indicators database; International Road Federation, } \\
\text { World Road Statistics }\end{array}$ \\
\hline $\begin{array}{l}\text { Revised Combined Polity Score } \\
\text { (Polity2) }\end{array}$ & Polity IV / Transparency International \\
\hline Gini Coefficient & Standardized World Income Inequality Database \\
\hline
\end{tabular}




\section{Annex Table 2. Country and Territory Groups}

Advanced Australia, Austria, Belgium, Canada, Cyprus, Czech Republic, Denmark, Estonia, Finland,

Economies $\quad$ France, Germany, Greece, Hong Kong SAR,* Iceland, Ireland, Israel, Italy, Japan, Korea, Latvia, Lithuania, Luxembourg, Macao SAR,* Malta, Netherlands, New Zealand, Norway, Portugal, Puerto Rico, San Marino,* Singapore, Slovak Republic, Slovenia, Spain, Sweden, Switzerland, Taiwan Province of China,* United Kingdom, United States

Emerging Market
Economies
Albania, Algeria, Angola, Antigua and Barbuda, Argentina, Armenia, Azerbaijan, The Bahamas,* Bahrain, Barbados, Belarus, Belize, Bosnia and Herzegovina, Botswana, Brazil, Brunei Darussalam, Bulgaria, Cabo Verde, Chile, China, Colombia, Costa Rica, Croatia, Dominica, Dominican Republic, Ecuador, Egypt, El Salvador, Equatorial Guinea, Fiji, Gabon, Georgia, Grenada, Guatemala, Guyana, Hungary, India, Indonesia, Iran, Iraq, Jamaica, Jordan, Kazakhstan, Kosovo,* Kuwait, Lebanon, Libya, Macedonia FYR, Malaysia, Maldives, * Marshall Islands,* Mauritius, Mexico, Micronesia,* Montenegro, Morocco, Namibia, Nauru,* Oman, Pakistan, Palau,* Panama, Paraguay, Peru, Philippines, Poland, Qatar, Romania, Russia, Samoa, Saudi Arabia, Serbia, Seychelles, ${ }^{*}$ South Africa, Sri Lanka, St. Kitts and Nevis, St. Lucia, St. Vincent and the Grenadines, Suriname, Swaziland, Syria, Thailand, Timor-Leste, Tonga, Trinidad and Tobago, Tunisia, Turkey, Turkmenistan, Tuvalu,* Ukraine, United Arab Emirates, Uruguay, Vanuatu, Venezuela

\begin{tabular}{|c|c|}
\hline $\begin{array}{c}\text { Low-Income } \\
\text { Developing } \\
\text { Countries }\end{array}$ & $\begin{array}{l}\text { Afghanistan, Bangladesh, Benin, Bhutan, Bolivia, Burkina Faso, Burundi, Cambodia, Cameroon, } \\
\text { Central African Republic, Chad, Comoros, Democratic Republic of the Congo, Republic of } \\
\text { Congo, Côte d'Ivoire, Djibouti, Eritrea, Ethiopia, The Gambia, Ghana, Guinea, Guinea-Bissau, } \\
\text { Haiti, Honduras, Kenya, Kiribati,* Kyrgyz Republic, Lao P.D.R., Lesotho, Liberia, Madagascar, } \\
\text { Malawi, Mali, Mauritania, Moldova, Mongolia, Mozambique, Myanmar, Nepal, Nicaragua, } \\
\text { Niger, Nigeria, Papua New Guinea, Rwanda, Senegal, Sierra Leone, Solomon Islands, Somalia,* } \\
\text { South Sudan, Sudan, São Tomé and Príncipe, Tajikistan, Tanzania, Togo, Uganda, Uzbekistan, } \\
\text { Vietnam, Yemen, Zambia, Zimbabwe }\end{array}$ \\
\hline $\begin{array}{c}\text { Countries and } \\
\text { Territories with } \\
\text { Average Annual } \\
\text { Temperature above } \\
15^{\circ} \mathrm{C}\end{array}$ & $\begin{array}{l}\text { Algeria, American Samoa, Angola, Anguilla, Antigua and Barbuda, Argentina, Australia, } \\
\text { Bahrain, Bangladesh, Barbados, Belize, Benin, Bhutan, Botswana, Brazil, Brunei Darussalam, } \\
\text { Burkina Faso, Burundi, Cabo Verde, Cambodia, Cameroon, Central African Republic, Chad, } \\
\text { Colombia, Comoros, Democratic Republic of the Congo, Republic of Congo, Costa Rica, Cuba, } \\
\text { Curaçao,* Cyprus, Côte d'Ivoire, Djibouti, Dominica, Dominican Republic, Ecuador, Egypt, El } \\
\text { Salvador, Equatorial Guinea, Eritrea, Ethiopia, Fiji, Gabon, The Gambia, Ghana, Grenada, } \\
\text { Guadeloupe,* Guatemala, French Guiana,* Guinea, Guinea-Bissau, Guyana, Haiti, Honduras, } \\
\text { India, Indonesia, Iraq, Israel, Jamaica, Jordan, Kenya, Kuwait, Lao P.D.R., Lebanon, Liberia, } \\
\text { Libya, Madagascar, Malawi, Malaysia, Mali, Malta, Martinique,* Mauritania, Mauritius, Mexico, } \\
\text { Montserrat, Morocco, Mozambique, Myanmar, Namibia, Nepal, New Caledonia, Nicaragua, } \\
\text { Niger, Nigeria, Oman, Pakistan, Panama, Papua New Guinea, Paraguay, Philippines, Puerto Rico, } \\
\text { Qatar, Reunion,* Rwanda, Samoa, Saudi Arabia, Senegal, Sierra Leone, Singapore, Solomon } \\
\text { Islands, Somalia, South Africa, South Sudan, Sri Lanka, St. Kitts and Nevis, St. Lucia, St. } \\
\text { Vincent and the Grenadines, Sudan, Suriname, Swaziland, Syria, São Tomé and Príncipe, } \\
\text { Tanzania, Thailand, Timor-Leste, Togo, Tonga, Trinidad and Tobago, Tunisia, Turkmenistan, } \\
\text { Turks and Caicos,* Uganda, United Arab Emirates, Uruguay, Vanuatu, Venezuela, Vietnam, } \\
\text { Virgin Islands (US), West Bank and Gaza, Yemen, Zambia, Zimbabwe }\end{array}$ \\
\hline $\begin{array}{c}\text { Countries with } \\
\text { Province-Level Data }\end{array}$ & $\begin{array}{l}\text { Albania, Argentina, Australia, Austria, Bangladesh, Belgium, Benin, Bolivia, Bosnia and } \\
\text { Herzegovina, Brazil, Bulgaria, Canada, Chile, China, Colombia, Croatia, Czech Republic, } \\
\text { Denmark, Ecuador, Egypt, El Salvador, Estonia, Finland, France, Germany, Greece, Guatemala, } \\
\text { Honduras, Hungary, India, Indonesia, Iran, Ireland, Italy, Japan, Jordan, Kazakhstan, Kenya, } \\
\text { Korea, Kyrgyz Republic, Latvia, Lesotho, Lithuania, Macedonia FYR, Malaysia, Mexico, } \\
\text { Mongolia, Morocco, Mozambique, Nepal, Netherlands, Nicaragua, Nigeria, Norway, Pakistan, } \\
\text { Panama, Paraguay, Peru, Philippines, Poland, Portugal, Romania, Russia, Serbia, Slovak } \\
\text { Republic, Slovenia, South Africa, Spain, Sri Lanka, Sweden, Switzerland, Tanzania, Thailand, } \\
\text { Turkey, Ukraine, United Arab Emirates, United Kingdom, United States, Uruguay, Uzbekistan, } \\
\text { Venezuela, Vietnam }\end{array}$ \\
\hline
\end{tabular}

Source: Authors' compilation.

* Not included in the main regression analysis. 


\section{Annex 2. Modeling Optimal Adaptation}

Section IV.C extends the original DIG model to incorporate direct investment in adaptation strategies. The main addition is the inclusion of private adaptation and public subsidies to private adaptation, whereas damages are modeled as before. In the absence of any adaptation measure, increased temperature causes gross damage, denoted by $G D_{j t}$, at time $t$ in sector $j$. The gross damage is expressed as a fraction of sectoral output:

$$
g d_{j t}=\frac{G D_{j t}}{q_{j t}}=\mathrm{f}(T) .
$$

Gross damage can be reduced by investing in adaptation. Firm i's capacity to adapt to climate change is denoted by $O_{i, j t}$. It is increasing in firm i's protection expenditures $A D_{i, j t}$ as well as in the total sectoral protection expenditures $\overline{A D}_{j t}=\int_{0}^{1} A D_{i, j t} \mathrm{di} \cdot{ }^{17}$ The residual damage for firm $i$ in sector $j$ is

$$
\Omega_{i, j t}=\frac{g d_{j t}}{O_{i, j t}\left(A D_{i, j t}, \overline{A D}_{j t}\right)^{\phi}},
$$

in which the marginal damage reduction from adaptation spending is decreasing. The positive parameter $\phi$ is the elasticity of damage reduction to the level of adaptation.

If the cost of a unit of protection is equal to $P_{A D, t}$ and the functional form for the capacity to adapt is $O_{i, j t}\left(A D_{i, j t}, \overline{A D}_{j t} ; \varsigma\right)=A D_{i, j t} \overline{A D}_{j t}^{\varsigma}$ (with $0 \leq \varsigma \leq 1$ ), then cost minimization by firms in the symmetric equilibrium $A D_{i, j t}=\overline{A D}_{j t}$ determines the optimal level of adaptation expenditure for each firm

$$
A D_{i, j t}=\left(\phi \frac{G D_{j t}}{P_{A D, t}}\right)^{\frac{1}{1+\phi(1+\varsigma)}} .
$$

The optimal level of firm-specific residual damage is then

$$
\Omega_{j t}=\frac{g d_{j t}}{A D_{j t}^{\phi(1+\varsigma)}},
$$

which can be shown to be socially suboptimal.

\footnotetext{
${ }^{17}$ Many adaptation measures have the nature of public goods; hence, firms benefit from total sectoral protection spending.
} 
The social planner's cost function, $\operatorname{Tot}_{i, j t}$, differs from that of individual firms

$$
T o t D_{i, j t}^{S P}=G D_{j t}\left(A D_{j t}^{S P}\right)^{-\phi(1+\varsigma)}+P_{A D, t} A D_{j t}^{S P}
$$

Minimizing the social cost gives socially optimal adaptation expenditures

$$
A D_{j t}^{S P}=\left[\phi(1+\varsigma) \frac{G D_{j t}}{P_{A D, t}}\right]^{\frac{1}{1+\phi(1+\varsigma)}} .
$$

It can be shown that private agents invest less than the socially optimal amount. The adaptation spending gap (as a fraction of the socially optimal adaptation spending) is equal to

$$
1-\left(\frac{1}{1+\varsigma}\right)^{\frac{1}{1+\phi(1+\varsigma)}}
$$

It can also be shown that the socially optimal amount of adaptation expenditures can be achieved if subsidies in the amount of $v_{\varsigma, j t}$ per unit cost of protection are paid by the government to the firms

$$
v_{\varsigma, j t}=\frac{\varsigma}{(1+\varsigma)} .
$$

